\title{
瀬戸内におけるある花崗岩体の載荷実験結果の解析
}

\author{
大西千秋※
}

\begin{abstract}
Analysis on the Results of Loading Test of some Kind of Setouchi Granite mass
\end{abstract}

by Chiaki Ōnishi,

\section{要 旨}

本論文は，瀬戸内花崗岩体に属する中国四国連絡送電線高鉄塔基礎地盤について，次の緒言に示さ れた著者の行なった各種調查のうちで，特にその地盤を構成する風化花崗岩いわゆる真砂体の外力に 対する变形特性を見出すために，4 か所において表面下深度 $2 \mathrm{~m}$ から最大深度 $13 \mathrm{~m}$ までの間の数階の レベルにおける自由表面で載荷実験と最終深度における繰返し載荷実験とを行なって得られた結果と， その解析およびそれらに対する考察を述べたものである。

載荷実験をかくの如く数階のレベルで行なったのは，鉄塔基礎の許容支持力地盤が現われるレベル を見出すためである。また繰返し載荷実験は風圧の変化により鉄塔が傾動し，これが基礎地盤におよ ぼす繰返し荷重に対処するための基礎資料を提供する目的を持つものである。

\section{1. 緒言}

中国四国連絡送電線（中四幹線）は愛媛県西条市に新設された電源開発伊予变電所を起点とし，今 治市波止浜から馬島，中渡島，大島，大三島，大久野島を足がかりに瀬戸内海を横断して，広島県竹 原市忠海で中国本土にわたり，さらに西進して広島県安芸町の中国電力広島変電所にいたる 亘長 $125 \mathrm{~km}$ の 220kV超高圧送電線である（図版 1，2，4参照）。そのうち，島づたいの海峡部には 径間 $2,357 \mathrm{~m}$ を最長とし，1,000 $\mathrm{m}$ をこえる長径間が数か所あり，その鉄塔も，高さ $226 \mathrm{~m}$, 重量約 $770 \mathrm{ton}$ 最大とし, 高さ $100 \mathrm{~m}$ をこえるものが 7 基設けられている。イタリーのメッシナ海峡横断の 
架空送電線路 ${ }^{1}$ の鉄塔は, 前記の鉄塔と同程度の規模で海峡部の径間は $3,645 \mathrm{~m}$ である。この径間は 前記の $2,357 \mathrm{~m}$ よ著しく長いが, 中国四国連絡送電線路の特徴は, 前述の如く多数の海峡を横断し ていることである。

海峡横断の鉄塔規模は従来のものに比して著しく巨大なものであるのに対して本路線通過地点の地 質は殆んど全部風化花崗岩であり, 相当深いところまで風化がおよんで真砂化していると推定された ので，高鉄塔の基礎地盤にあたる部分の地質条件を明らかにすることが非常に重要であった。 そのために次の如き各種の方法による調査, 実験を行なった。

(1) 地表地質調查

(2) 測量：三角測量のほか海上径間においてはTellurometer 使用

（3）電気探査：比抵抗法, 探查深度 $60 \mathrm{~m}$, 測点数 118 点, 測線総延長 $17,348 \mathrm{~m}$

（4）ボーリングおよび貫入試験：平均深度 $20 \mathrm{~m}$, 全孔数 52 孔, 総延長 $1,127.9 \mathrm{~m}$, 標準貫入試験, 電気式コーン貫入試験。

（5）土質および岩石試験：J I S 規格による土質試験, 黒雲母のX X 線回折実験, 岩石試料の弾性波 速度測定

（6）初載荷実験および繰返し載荷実験：初載荷実験 9 地点(深度別を含む), 繰返し載荷実験 4 地点

（7）弾性波速度：各鉄塔基礎掘削面

（8）真砂土現場締固め試験

（9）埋戻し真砂土のコーン:貫入試験

(10) 基礎上引耐力試験：掘削工法の差異 (1：1，1：0，タコツボ, $1: 0.3$ )

（11） 鉄塔振動実験：大久野島ルートNo.5 号, No.6 号塔体および基礎の振動

以上の調查，実験資料は電源開発資料として電源開発株式会社に保管されてある。

本論文で取り扱ったのは，大久野島ルートNo.2 号（大三島），同No. 3 号（大久野島），同NNo.6 号 (忠海) および来島ルートNo.3 号（馬島）の 4 か所の鉄塔の基礎地盤に対して行なった初載荷実験 および繰返し載荷実験に関するもので, 調査資料中でも最も重要な部分を占めるものである。

なお，本論文は同名の「京都大学審査学位論文」の大要を公表したものである。ただし測定結果 の図示は紙面の関係で大久野島ルートNo.2 号 (大三島) のみにとどめ，その他の箇所はこれを割愛 した。

\section{2. 実験地盤の地質摘要}

大久野島ルート No. 2 号, №. 3 号. No. 6 号鉄塔の基盤地質を構成するものは, 通称広島型に属する黒 雲母花崗岩で, その組識は概して粗粒, かつ一般に風化, 変質が著しい。風化状態は表層より深部に 向って漸移しており，構成鉱物が完全に分離していわゆる真砂と化し，あるいは原岩の様相をとどめ 
てはいるが，わずかな外力によっても崩壊し易い状態になっている。ことに大久野島ルートNo.2 号鉄 塔の基礎地質は極わめて風化が進んでいるために地質調査や地耐力実験には最も念を入れたところで ある（図版 $2 ， 5 ， 6 ， 7$ ，参照）。

来島ルートNo. 3 号鉄塔の基盤は領家 II 型といわれている細粒の黒雲母花崗岩ないし石英閃緑岩質黒 雲母花崗岩で岩相不均質である。その風化度は前者に比してかなり低い。

\section{3. 初載荷実験}

(1)実験期間

自昭和 36 年 5 月 7 日一至昭和 36 年 6 月 3 日

(2)実験位置

大久野島ルートNo.2 号鉄塔, c脚, EL (海抜高) $=7.47,4.47,1.97 \mathrm{~m}$

大久野島ルートNo.3 号鉄塔, a脚, $E L=8.31,5.01 \mathrm{~m}$

大久野島ルートNo. 6 号鉄塔, c脚, $\mathrm{EL}=12.22,7.52 \mathrm{~m}$

来島ルートNo. 3 号鉄塔, b脚, $E L=74.64,74.14 \mathrm{~m}$

(3)実験方法

鉄塔基礎地盤に $2.2 \mathrm{~m} \times 2.2 \mathrm{~m}$ の試掘を実施し，指定深度に実験基盤面を出し，表面はできるかぎ り平滑に仕上げる，その上にプラストンまたはセメントペーストを打設して加圧板（載荷板）を置き， さらにその上にオイルジャッキ, 円筒ブロックおよび球座等を設置して支柱により支圧板に支承させ る。掘削土砂はカマスに入れてこれを載荷台に載せ，それを支圧面とする。

本実験は「J I S A 1215」および「JES 建築3001」に準じて行なった。加圧板は半径 $15 \mathrm{~cm}$ （面積約 7 $07 \mathrm{~cm}$ ），厚さ約 $2.5 \mathrm{~cm}$ の鉄製円板を使用し，オイルジャッキに加えた圧力はオイルポンプに取り付け た荷重計（1 目盛 1 ton ）によって測定する。基盤の変位は加圧板の上に置かれた $1 / 100 \mathrm{~mm}$ 目盛りの のダイヤルゲージ 2 個で読み取り，その平均值をもって沈下量とした。

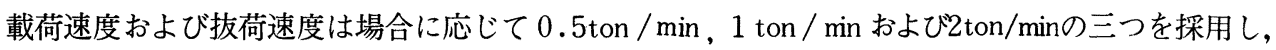
最終荷重を16 ton $\left(226 \mathrm{ton} / \mathrm{m}^{2}\right)$ とした。毎回の載荷後 5 分間は 1 分ごとに，以後10分ごとに沈下が 停止するまで沈下量の測定を続け，その後次の載荷に移った。これを継続し，荷重一沈下曲線が降伏 点に達すると 推定されたとき, 測定を中止し, 次に載荷と全く逆の手順によって抜荷して各段の反 発量を測定し，零荷重となってから，なお30分間測定を続けた後実験を中止する。

\section{4. 繰返し載荷実験}

(1)実験期間

自昭和36年 5 月 21 日一至昭和36年 6 月 7 日

(2)実験位置

大久野島ルートNo.2 号鉄塔, c脚, E L (海抜高) $=0.97 \mathrm{~m}$ 
大久野島ルートNo. 3 号鉄塔, a脚, $E L=4.01 \mathrm{~m}$

大久野島ルートNo. 6 号鉄塔, c脚， $\mathrm{EL}=6.52 \mathrm{~m}$

来島ルートNo. 3 号鉄塔, b脚, $E L=73.14 \mathrm{~m}$

(3)実験方法

初載荷実験終了後, その最終レベルの表面をさらに $1.0 \mathrm{~m}$ 掘さくして得る基礎床付予定地盤につい

て前記の初載荷実験と全く同様の方法を採用した。全荷重の繰返し範囲は $0 \leftrightarrows 5$ tonおよび $0 \leftrightarrows 10$ tonで, 繰返し回数の最大值は場所により10および23を採用した。ただし，大久野島ルートNo.2 号鉄塔c脚は 沈下量著しきため $0 \leftrightarrows 10$ tonは 6 回をもって実験を中止した。

\section{5. 実験結果（図版 3 参照）}

\section{（1）初載荷実験結果}

実験によって得られた各鉄塔基礎地盤のEL（海抜高）別の荷重一沈下量関係を示す数值は表一1〜 表一 4 に示すとおりである。次に測定結果を表わす荷重一時間，沈下一時間，ならびに荷重一沈下曲 線は図版 3 に総括して示してある。この荷重一沈下曲線の非直線性を示すため両対数方眼紙上にプロ ットしたのが図ー 1 である。

まず荷重一沈下曲線をみるに，注目すべきは大久野島ルートNo. 2 号鉄塔，c脚では曲線の勾配がき わめて急であるが, この鉄塔脚以外の場合は曲線勾配はゆるやかになり最終荷重16tonに至っても明 確な降伏点はみられないという特徴が見出されている。

次にこれらの両対数表現で表わした荷重一沈下曲線をみると, 荷重一沈下量の関係は一般に直線的 でないことがわかる。大久野島ルートNo.2 号鉄塔, c脚, EL=7.47 m, EL=4.47 $\mathrm{m}$ は 3 ton, EL= $1.97 \mathrm{~m}$ は 5 tonにおいて, それぞれ折点が現われている。大久野島ルートNo. 3 号鉄塔, a脚, EL= $8.31 \mathrm{~m}$ は 9 tonに折点をみるが， EL= $5.01 \mathrm{~m}$ では最大荷重16ton に至るも折点をみず直線である。

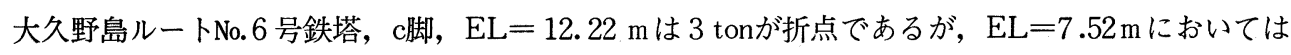
16tonに達しても直線である。来島ルートNo. 3 号鉄塔, b脚, EL=74. $64 \mathrm{~m}$ は 9 tonのところで折点 が出ているが，EL=74.14 m では16ton に至るまでほほ直線である。

沈下量は大久野島ルートNo. 2 号鉄塔, c脚が最も大きく, EL= $1.97 \mathrm{~m}$ において最終荷重 16 tonで 沈下量は $1.923 \mathrm{~cm}$ である。次に大久野島ルートNo.3 号鉄塔, a脚，大久野島ルートNo.6 号鉄塔，c脚の 順に減少し,来島ルートNo. 3 号鉄塔b脚は $\mathrm{EL}=74.14 \mathrm{~m}$ において最終荷重 $16 \operatorname{ton}$ で沈下量は $0.256 \mathrm{~cm}$ と なり最も小さい。一般に荷重の増加とともに沈下量は増加するが，梁度が増すにしたがって，すなわ ちELが減少するにしたがって減少する傾向がある。ただし比較的浅いところでは風化状態の不均一 よって部分的に深度が増しても沈下量が増加するところもある。

以上の実験結果から得られた荷重一沈下量特性には鉄塔基礎地盤の場所および深度の変化の実態が よく把握されているが, 風化花崗岩体（真砂体）特有の漸移的風化構造をよく反映していると思われ る。一般に広島型花崗岩は風化が著しく, 特に大久野島ルート No. 2 号鉄塔, c脚，基礎地盤は注意す 
ベきところである。これに比べて領家II型花崗岩の風化度はかなり低いことがよく現われている。

（2）繰返し載荷実験結果

繰返し載荷実験最終サイクルにおける荷重と加荷重過程の沈下量 $\mathrm{v}_{\mathrm{N}}$ 示す数值は表ー11〜表ー14に 示してある。ここに沈下量 $\mathrm{v}_{\mathrm{N}}$ は, 最終サイクルを第 $\mathrm{N}$ 回目とすればN回目の加荷重過程の全沈下量 （初載荷前の地表のレベルから測ったもの） $\mathrm{w}_{\mathrm{N}}$ から第 $\mathrm{N}-1$ 回目のサイクルで見出された残留歪 $\widetilde{\mathrm{w}} \mathrm{N}-1$ を差引いたものである。

すなわち

$$
\mathrm{v}_{\mathrm{N}}=\mathrm{w}_{\mathrm{N}}-\widetilde{\mathrm{w}}_{\mathrm{N}}-1
$$

表一11の結果を両対数表現で表わしたのが図一6で ある。また図一 7 には繰返し, 載荷実験の初めの数サ イクルと最終の 2 サイクルの模様が示されてある。

実験結果によれば，繰返し回数が増すにしたがって 沈下の増加率は減少する傾向がある。

また, 最終サイクルの加荷重過程における荷重一沈 下量 $\left(\mathrm{v}_{\mathrm{N}}\right)$ 関係は初載荷実験におけると同様に非直 線的である。大久野島ルートNo. 3 号鉄塔，a脚，EL

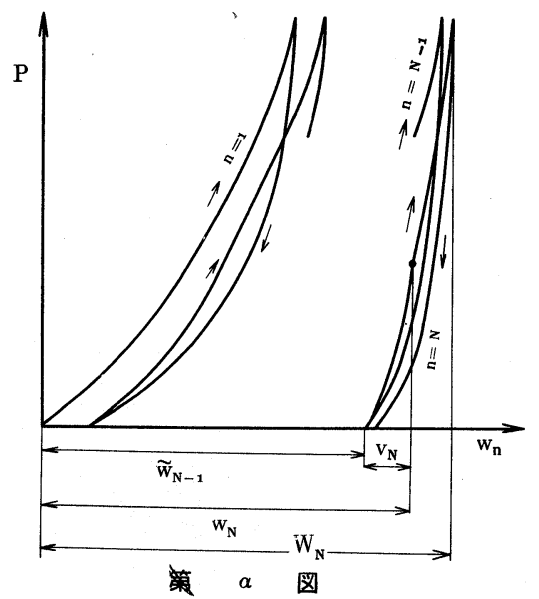
$=4.01 \mathrm{~m}$ では $\mathrm{P}=0 \leftrightarrows 5$ ton, $\mathrm{P}=0 \leftrightarrows 10$ tonともに 3 tonにおいて折点が現われ，大久野島ルートNo.6 号鉄塔， $\mathrm{c}$ 脚， EL $=6.52 \mathrm{~m}$ では $\mathrm{P}=0 \rightleftarrows 10$ ton にお いて 4 tonが折点である。これらの折点より先きは曲線のw軸に対する勾配は急となる。これは沈下の 増加率が減少し硬化現象を呈することを意味する。そのほかの鉄塔脚地盤においては折点をみず 1 本の直線に沿う変形を示している。

沈下量は大久野島ルートNo.2 号鉄塔， $\mathrm{c}$ 脚が最も大きく, $\mathrm{EL}=0.97 \mathrm{~m}$ において $\mathrm{P}=0 \rightleftarrows 5$ ton， 23回で沈下量 $0.575 \mathrm{~cm}, \mathrm{P}=0 \leftrightarrows 10 \mathrm{ton}, 6$ 回で沈下量 $0.937 \mathrm{~cm}$ となり, 沈下量が著しく大きくなるため に実験を中止し，基礎底面を広げたところである。次に大久野島ルートNo.3 号鉄塔， a 脚，大久野島ル 一トNo. 6 号鉄塔， c 脚では，この順に沈下量が減少している。来島ルートNo.3 号鉄塔， b 脚では, $\mathrm{EL}=73.14 \mathrm{~m}, \mathrm{P}=0 \rightleftarrows 5 \mathrm{ton}, 10$ 回で沈下量 $0.062 \mathrm{~cm}, \mathrm{P}=0 \rightleftarrows 10 \mathrm{ton}, 10$ 回では沈下量 $0.093 \mathrm{~cm}$ となり最も小さい。前述の初載荷実験結果と同様の傾向が現われている。

\section{6. 結果の解析と考察}

以上の諸実験に明らかにみられるように，各鉄塔脚基礎地盤の表面加圧による変形は下記に述べる 新しい方法によって解折を行ない，それに対して考察を試みた。

（1）荷重一沈下量曲線の非直線性

まず，初荷重一沈下量特性から 4 力所の地盤全体としての変形特性の解析と考察を記述しよう。4 
か所の実験場所，すなわち大久野島ルートNo. 2 号鉄塔， c 脚，同No. 3 号鉄塔， a 脚，同No. 6 号鉄塔， $\mathrm{c}$ 脚，および来島ルートNo.3 号鉄塔， b 脚の種々の EL（海抜高），加圧面に対して行なわれた全荷 重 $\mathrm{P}$, 荷重強度 $\mathrm{q}$ に対する加圧面の沈下量 $\mathrm{w}$ の実測值はそれぞれ表一 1 , 表一 2 , 表一 3 および表一 4 に示した通りである。この結果から $\mathrm{P}-\mathrm{w}$ 関係を両対数によって表示したものは図一 1 ，である。

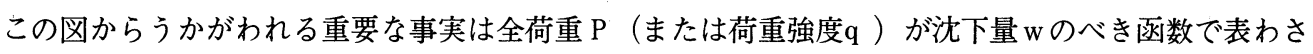
れるということである。そこで筆者は全荷重または荷重強度を沈下量のべき函数で表わし得る式を導 くことを試みた。

いま, $\sigma$ を応力, $\varepsilon$ を歪, A を応力の次元をもつ定数, $\mu$ を無次元の定数とすれば, 多くの物質に ついて,

$$
\sigma=\mathrm{A}_{\varepsilon}^{\mu}
$$

という関係が見出されている2)

また, Boussinesq ${ }^{3)}$ の式は，半無限完全弾性体の表面に完全剛体の半径 $\mathrm{r}=\mathrm{a}$ の円盤をおき，この 円盤に全荷重 $\mathrm{P}$ を加えた場合の, 加圧板下底面の沈下量 $\mathrm{w}$ と $\mathrm{p}$ との関係を示すものであって,

$$
\mathrm{w}=\frac{\mathrm{P}\left(1-\nu^{2}\right)}{2 \mathrm{aE}_{s}}
$$

である。ここに $\mathrm{E}_{s}, \nu$ はそれぞれ半無限完全弾性体の静ヤング率およびポアソン比である。いま, $\nu=0.25$ と仮定し, 荷重強度を $\mathrm{q}$ とすれば $\mathrm{q}=\mathrm{P} / \pi \mathrm{a}^{2}$ であるから(2)式は,

$$
\mathrm{q}=\mathrm{E}_{s}\left(\frac{\mathrm{w}}{1.5 \mathrm{a}}\right)
$$

に変形できる。いま(1)式の応力 $\sigma$ と歪 $\varepsilon$ をそれぞれ(3)式の q と w $/ 1.5{ }_{a}$ に対応せしめ, そして定数 $\mathrm{A}$ をBに定数 $\mu を \mu^{\prime} に$ 書き改めると(1)式と同じ形の次の式が得られる。

$$
\mathrm{q}=\mathrm{B}\left(\frac{\mathrm{w}}{1.5 \mathrm{a}}\right) \mu^{\prime}
$$

これが求むる式である。ここにBはA と同様に応力の次元をもつ定数であり， $\mu^{\prime} は \mu$ と同様な無次元 の定数である。実験值の解析はこの(4)式によって行なった。ここで $\mu^{\prime} \neq 1$ である場合は荷重一沈下量 曲線は非直線である。 $\mu^{\prime}=1$ となる特別の場合は(4)式は被圧体が完全弾性体である場合の(3)式に一致 し, $\mathrm{B}$ は $\mathrm{E}_{s}$ 等しくなる。

さきの(1)式における定数 $\mu$ は歪硬化指数（strain hardening exponent）と称せられているもので あるが，新しく求められた(4)式における $\mu^{\prime} は ， \mathrm{w} / 1.5 \mathrm{a}$ を後述するように見掛歪と呼ぶことにする から, 見掛歪硬化指数という名称をつけよう。(4)式における $\mu^{\prime}$ は, 次に示すように, $\mathrm{q}-\mathrm{w}$ 曲線の曲り 方を支配するものである。すなわち，qの $\mathrm{w}$ に対する第 1 階微分係数を(4)式によって求めると

$$
\frac{\mathrm{d} \mathrm{q}}{\mathrm{dw}}=\frac{\mathrm{B}}{(1.5 \mathrm{a})^{\mu^{\prime}}} \cdot \mu^{\prime} \mathrm{w}^{\mu^{\prime}-1}
$$


となる。

$$
\mathrm{w}=0 \text { では }
$$

$$
\begin{aligned}
& \mu^{\prime}>1 \cdots \cdots \cdots \frac{\mathrm{dq}}{\mathrm{dw}}=0 \\
& \mu^{\prime}=1 \cdots \cdots \cdots \cdot \frac{\mathrm{dq}}{\mathrm{dw}}=\frac{(\mathrm{B}) \mu^{\prime}=1}{1.5 \mathrm{a}} \\
& \mu^{\prime}<1 \cdots \cdots \cdots \cdot \frac{\mathrm{dq}}{\mathrm{dw}}=\infty
\end{aligned}
$$

後述の(9)式が示すとおり $\mathrm{k}, \mathrm{h}$ を定数とすれば $\mu^{\prime}=\mathrm{k} \quad(\mathrm{B}+\mathrm{h})$ であるから $(\mathrm{B}) \mu_{\mu^{\prime}=1}=\frac{1}{\mathrm{k}}-\mathrm{h}$ である。 第 2 階微分係数は

$$
\frac{\mathrm{d}^{2} \mathrm{q}}{\mathrm{dw}^{2}}=\frac{\mathrm{B}}{(1.5 \mathrm{a})^{\mu}} \cdot \mu^{\prime}\left(\mu^{\prime}-1\right) \mathrm{w}^{\mu^{\prime}-2}
$$

である。w $>0$ では

$$
\begin{aligned}
& \mu^{\prime}>1 \cdots \cdots \cdots \cdot \frac{\mathrm{d}^{2} \mathrm{q}}{\mathrm{dw}^{2}}>0 \\
& \mu^{\prime}=1 \cdots \cdots \cdots \cdot \frac{\mathrm{d}^{2} \mathrm{q}}{\mathrm{dw}^{2}}=0 \\
& \mu^{\prime}<1 \cdots \cdots \cdots \cdot \frac{\mathrm{d}^{2} \mathrm{q}}{\mathrm{dw}^{2}}<0
\end{aligned}
$$

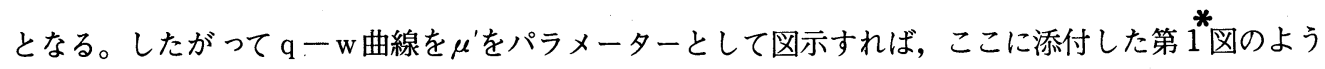
になる。この図からわかるとおり，沈下量の同一微小増加 $\mathrm{d} \mathrm{w}$ を生ずるに必要な荷重強度の増加 $\mathrm{d} \mathrm{q}$ は, $\mu^{\prime}<1$ なる場合には $\mathrm{w}$ の増大とともに次第に大きくなる。これは $\mathrm{w} の$ 増大とともに物質は次第に硬くなる ことを意味する。 $\mu^{\prime}<1$ なる場合にはこれと反対に次第に軟くなるような現象を示す。また $\mu^{\prime}=1$ の場合 にはwが増加しても硬さは変らない。 以上は $\mu^{\prime}$ もつ重要な意味である。

$\mu^{\prime}, \mathrm{B}$ の值は, 両対数表現の葆重一 沈下量関係を示す直線上の任意の 2 点 における值を用いて，次に示す(7)，(8) 両式によって計算した。

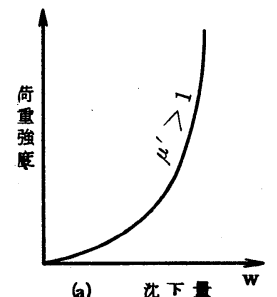

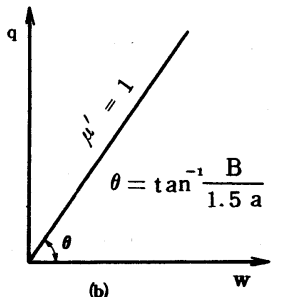

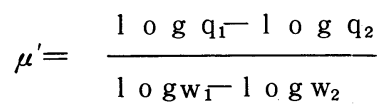

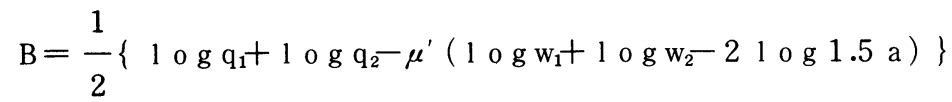

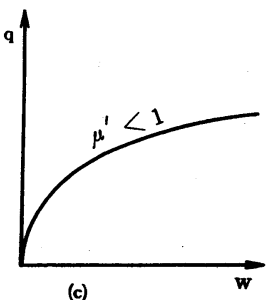

(c) 
かくの如く計算された各鉄塔基礎地盤における E L (海抜高) 別の $\mu^{\prime}, \mathrm{B}$ の数值は表一 5 に示して ある。両対数表現の荷重一沈下関係が一つの折点をもつ場合は，2 直線を折点で分離して，それぞれ の直線について $\mu^{\prime}$ を求めた。第 5 表において $\mu^{\prime} の$ 值の変化を分類した結果をみると， $\mu^{\prime}$ は最小值 0.55 , 最大值1.56の範囲に変化しており， $\mu^{\prime}<0.9$ である場所は 4 か所, $\mu^{\prime} \fallingdotseq 1 \quad\left(0.96 \leqq \mu^{\prime} \leqq 1.03\right)$ となる 場所は 4 か所， $\mu^{\prime}>1.1$ である場所は 7 か所であった。

なお, 表一 5 を注意してみると, 各鉄塔脚の基礎地盤の同一の E L に対し, 二つの異なる全荷重範 囲についてそれぞれ異なる值の片と B が得られている。それをみると全荷重が増加すると $\mu^{\prime} も \mathrm{~B} も$ 増 加している。すなわち $\mu^{\prime}, \quad \mathrm{B}$ とは互いに独立ではないということがうかがわれる。そこで, この地 域の瀬戸内花崗岩の風化体（真砂体）全体に対する $\mu^{\prime}$ と $\mathrm{B}$ との関係を見出すために, 上記の数值を図 示してみると，それは $\mathrm{k}, \mathrm{h}$ を定数とすれば

$$
\mu^{\prime}=\mathrm{k} \quad(\mathrm{B}+\mathrm{h})
$$

という比例関係を示す直線に沿うて配列することがわかった。

この図にさらに表一 5 の最後の 3 か所の基礎地盤の $\mathrm{E} \mathrm{L}=5.01,7.52,74.14 \mathrm{~m}$ に対しP $=1 \sim 16$ ton の範囲で得られた $\mu^{\prime}, \mathrm{B}$ の值を記入してみると，上記の直線に乗るので，(9)式の直線関係は，この 地域に対してかなり一般性をもつものと思われる。 $\mathrm{k}$ および $\mathrm{h} の$ 值を概算してみると $\mathrm{k}=0.136 \mathrm{~cm}$ $/ \mathrm{kg}, \mathrm{h}=-10.0 \mathrm{~kg} / \mathrm{cm}$ である。したがって,

$$
\mu^{\prime}=0.136 \quad(\mathrm{~B}-10.0)
$$

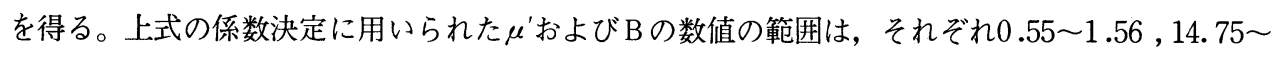
$21.34 \mathrm{~kg} / \mathrm{cn}^{2}$ である。(9)式は今後 $\mu^{\prime}$ の物理的意味を研究する上に重要な手がかりになると思われる。

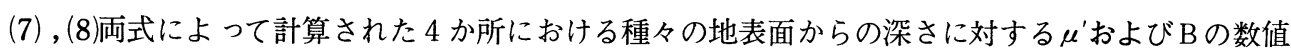
は表一 5 に示すとおりである。なお，同表には P 範囲お よび両対数表示における 2 直線の折点が示されている。表

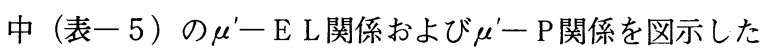
ものは，困一 2 である。

まず， $\mu^{\prime}-\mathrm{E}$ L関係（図一2）をみて注目される一般的 傾向は $\mu^{\prime}$ は E L が減少するにしたがい，すなわち深度が増 すにしたがって，一般に増大していることである。換言す れば，この地域の花崗岩の風化体は深部ほど，もし，その レベルを自由表面にして加圧するとすれば，その表面に一 定の沈下量を与えるための荷重は大であるということ，つ まり深部ほど物質が硬いということである。

次に,一定の $E L$ 值に対する $\mu$-P P関係をみると次の

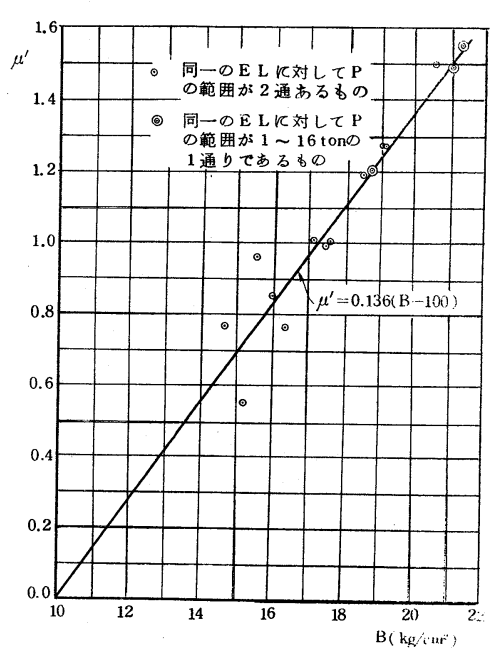

第 2 図 総ての $\mathrm{E} L$ に対する初載荷実験 における $\mu^{\prime}$ と B との関係 事実が認められる。 
大久野島ルートNo.3 号鉄塔， $\mathrm{c}$ 脚（困一 3 ）においては, $\mathrm{E} \mathrm{L}=7.47 \mathrm{~m}$ および $4.47 \mathrm{~m}$ では, $\mathrm{P}=3$ ton を境とし, $\mathrm{E} \mathrm{L}=1.97 \mathrm{~m}$ では $\mathrm{P}=5$ ton を境として, 全荷重の増加により $\mu$ は急速に減少するこ とを示している。

大久野島ルートNo. 3 号鉄塔, $\mathrm{a}$ 脚においては, $\mathrm{E} \mathrm{L}=8.31 \mathrm{~m}$ では, $\mathrm{P}=8.8$ tonを境として, 全荷重 の増加により, 同様に, $\mu^{\prime}$ は急速に減少する。ところが, $\mathrm{E} \mathrm{L}=5.01 \mathrm{~m}$ では, 全荷重 1 16 ton の範 囲で $\mu^{\prime}$ は定値を保っている。すなわち E L が8 $.31 \mathrm{~m}$ から $5.01 \mathrm{~m}$ に減少すると，Pの増加によって $\mu^{\prime}$ が急速に減少する現象が現われていることは注目すべきである。

大久野島ルートNo. 6 号鉄塔, $\mathrm{c}$ 脚においては, 前記NNo. 3 号鉄塔, $\mathrm{a}$ 脚と同様な現象が見出されてい る。すなわち, $\mathrm{E} \mathrm{L}=12.22 \mathrm{~m}$ では $\mathrm{P}=3$ tonを境として全荷重が増加すると $\mu^{\prime}$ は急速に減少している が, $\mathrm{E} \mathrm{L}=7.52 \mathrm{~m}$ では全荷重 $1 \sim 16$ ton の範囲で $\mu^{\prime}$ は定值を保っている。

来島ルートNo. 3 号鉄塔， b 脚においても，再び同様の事実が見出されている。すなわち， E L = $74.64 \mathrm{~m}$ では $\mathrm{P}=8.5$ tonを境として, 全荷重の増加により $\mu^{\prime}$ は急速に減少し，このレベルよりわずか $0.5 \mathrm{~m}$ 下方の $\mathrm{E} \mathrm{L}=74.14 \mathrm{~m}$ では全荷重 1 ～16tonの範囲において $\mu^{\prime}$ は一定值を保持している。

上記 4 か所のうち最後の 3 か所における共通な現象は,

（I）その場所特定の海抜高すなわち特定の深度では，P が 3 ないし 9 ton の比較的低い值を境と

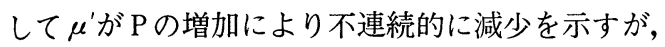

(II) この特定の深度よりも数 $10 \mathrm{~cm}$ ないし数 $\mathrm{m}$ 深い深度になると $\mathrm{P}=1 \sim 16 \mathrm{ton}$ の広範囲において， $\mu^{\prime}$ は一定值を保っているということである。この(II)の事実はこの場所の風化花崗岩体の先天的特 性であるか，または低深度において行なわれた載荷実験のある効果が深部におよしじ垷われた後 天的の性質であるか速断を許さないので，これは将来研究を要する現象であると思う。

大久野島ルートNo.2 号鉄塔, $\mathrm{c}$ 脚（図一 7) で得られた結果は, 上記 3 か所と異なり，Pの増 加に対して $\mu^{\prime}$ が定值を示す $\mathrm{E} L$ が見出されていないが, これは上記 3 か所と比較して地質的な特 例であるように思われる。

以上に述べた $\mu^{\prime}-\mathrm{P}$ 関係を示す事実のうちで特に興味あるものは, 荷重が増加中ある值を通過ると $\mu^{\prime}$ は急に小さくなることである。これはこの特定荷重を受けることによって真砂の粒子間の結合が変 化して $\mu^{\prime}$ の小さな物質に転移することを示すものと解釈し得る。

以上 4 か所の実験場所において各染度の露頭を観察した結果によれば，定性的ではあるが表面から の深さが大きいほど，すなわち E Lの小さいほど風化の程度が低いことがうかがわれる。この観察と， 前記の $\mu-\mathrm{E} L$ 関係（図一-2）に現われた事実，すなわちE Lの減少（表面からの深度の増加）とと

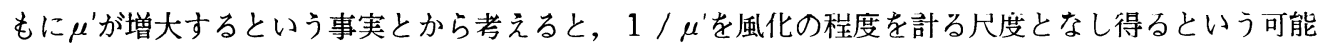
性が認められる。これは将来の研究問題である。すなわち, ある方法で風化度を定量化し，これと $1 / \mu^{\prime}$ との関係を研究するというテーマが考えられる。

また， $\mu^{\prime}$ - $\mathrm{P}$ 関係（図一-3）に現われた事実からみると, 風化程度の尺度となり得るところの $1 / \mu$ 
は一定範囲の荷重に対して規定されなければならないものと考えられる。

(2) 接線見掛ヤング率と割線見掛ヤング率

載荷実験によって得られた基礎地盤の変形特性を理解するために，次の方法を採用する。いま，比 $\mathrm{w} / 1.5 \mathrm{a}$ は無次元の量であるので, これを見掛歪 ${ }^{\prime}$ と称し

$$
\varepsilon^{\prime}=\frac{\mathrm{w}}{1.5 \mathrm{a}}
$$

とおく，そして $\mathrm{q} ー \varepsilon$ 曲線を作りこの曲線上の 1 点における $\mathrm{q} / \varepsilon^{\prime}$ を割線で表わし，これを割線見 掛ヤグ率と呼ぶ。一方同じ点における接点の傾斜 $\mathrm{d} \mathrm{q} / \mathrm{d} \boldsymbol{\varepsilon}^{\prime}$ を $\mathrm{E}$ 接線で表わし，これを接線見掛ヤング 率と称するならば, (4)式から

$$
\begin{aligned}
& \mathrm{E}^{\prime} \text { 割線 }=\frac{\mathrm{q}}{\varepsilon^{\prime}}=\frac{\mathrm{q}}{\frac{\mathrm{w}}{1.5 \mathrm{a}}}\left(\mathrm{kg} / \mathrm{cm}^{2}\right) \\
& \mathrm{E}^{\prime} \text { 接線 }=\frac{\mathrm{d} \mathrm{q}}{\mathrm{d} \boldsymbol{\varepsilon}^{\prime}}=\mu^{\prime} \frac{\mathrm{q}}{\mathrm{w}}\left(\mathrm{kg} / \mathrm{cm}^{2}\right)
\end{aligned}
$$

$\mathrm{E}^{\prime}$ 接線と $\mathrm{E}^{\prime}$ 割線の比は(12), (13)式より $1.5 \mathrm{a}$

$$
\mathrm{E}^{\prime} \text { 接線 } / \mathrm{E}^{\prime} \text { 割線 }=\mu^{\prime}
$$

である。したがって，これら 2 種類の見掛ヤング率は $\mu^{\prime}=1$ である岩盤に対しては, Boussinesq の式 (2)から導かれたところの(3)式で求められる真の静ヤング率 $\mathrm{E}_{s}$ と一致し， $\mathrm{E}^{\prime}$ 割線= $\mathrm{E}^{\prime}$ 接線= $\mathrm{E}_{s}$ となる。 非直線性を示す荷重一沈下曲線が見つけられると，曲線の各部分において割線見掛ヤング率と接線 見掛ヤング率をそれぞれ(12)式と(13)式によって求めることができる。このようにして 2 種類の見掛上の ヤング率を求め，それらの值が場所ごとの深度による変化および荷重強度の大きさによる変化を考察 すれば次のとおりである。

各鉄塔地盤において, $\mathrm{E} \mathrm{L}$ (海抜高) 別に $\mathrm{P}=5,6,10$ tonに対するE接線・E割線の值は表一 6 に示 すとおりである。これを図示したのが図一 4 である。

まず， E'接線・E割線と E L との関係をみると，荷重 5 tonおよび10tonに対しては， E L が減少す

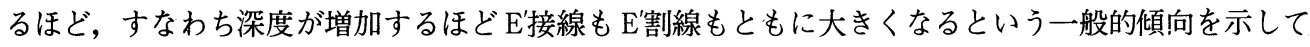
いる。ただし，大久野島ルートNo. 3 号鉄塔 a 脚の場合は特別である。すなわち前記の 3 か所に比較す ると，きわめて不規則な結果を示すが， $\mathrm{P}=10$ tonに対する $\mathrm{E}^{\prime}$ 接線だけは前 3 者の場合と同様に $\mathrm{E} \mathrm{L} の$ 減少に対し増加を示している。

上記の 4 地盤の各 $\mathrm{E} \mathrm{L}$ (海抜高)に対して $\mathrm{P}=1,2.4,6,8,10,12,14,16$ tonと荷重を変化した場合に対 応する E接線・E割線の計算值は表一7〜表一10に総括して示してある。これを図示したものは図 $-5-1$, 四一 5-2である。このうち，大久野島ルートNo. 2 号鉄塔， c 脚は特に沈下量大なるため, $\mathrm{E} \mathrm{L}=7.47 \mathrm{~m}$ においては $\mathrm{P}=5$ ton, $\mathrm{E} \mathrm{L}=4.47 \mathrm{~m}$ においては $\mathrm{P}=10$ tonを最終全荷重とした。図によ って各 $\mathrm{E} \mathrm{L}$ 別に全荷重と $\mathrm{E}^{\prime}$ 接線・E割線との関係を調べてみると， E接線・ $\mathrm{E}^{\prime}$ 割線の変化の模様は大 
別して一応 3 種類に分類できる。すなわち，(I荷重が大きくなるほど小さくなる場合，(II)低荷重の間 は変化がないが, 荷重が大きくなるにしたがって小さくなり凸凹状態を続ける場合, (而荷重が大きく なると逆に大きくなり凸凹状態を続ける場合のようである。

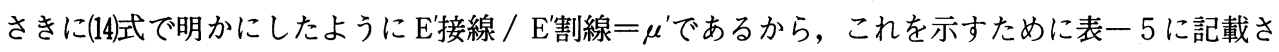
れてある $\mu^{\prime}$ の值を図一 $5-1$, 図一 $5-2$, に記入しておいた。定数 $\mu^{\prime}$ は前述したとおり, 荷重強度 (q)一沈下量(w)の測定值の両対数表示上の分布が一つの直線で近似されているとみて 7 式によって見出 されたものである。したがって, このようにして求められた $\mu^{\prime} の$ 值はある定った場所の風化花崗岩体 を巨視的に均質とみた場合の特性定数とみることができる。

$\mu^{\prime}$ の正確な求め方は q , wのすべての測定值を最小自乗法で処理する方法であるが，この方法で求 められたものと, かくの如く(7)式で求められたものとの間には著しき相違のないことは確かである。 ところが $\mathrm{E}^{\prime}$ 接線・E割線の計算值は $\mathrm{q}-\mathrm{w}$ 曲線の曲り方に支配されている，したがって，上述の如く (I)，(II)および(III)の 3 種類に分類されるような荷重に対する不規則性が見出されたのは当然である。

もっとも， q , wの測定值には測定䛊差が含まれていることは否定できないが，上記の不規則性が 全部測定誤差によるとは考えられない。したがって定性的には次のことが結論されると思う。すなわ ち, 上述の如き荷重に対する $E^{\prime}$ 接線・ $E^{\prime}$ 割線の変化の模様は, 瀬戸内花崗岩の風化体, すなわち真砂 体の構成鉱物の風化状態および各鉱物粒子の結合状態，両者の不規則分布に起因するものと想像され る。また，前述の如く真砂体を巨視的に取扱って，その特性定数 $\mu^{\prime} を$ 見出すことができたのであるが， 真砂体を微視的にみれば著しい不規則性のあることがうかがわれる。

（3）繰返し載荷実験結果に現われた特性

繰返し載荷寄験の $\mathrm{P}$ の範囲は $0 \rightleftarrows 5$ tonおよび $0 \rightleftarrows 10$ tonで, 繰返し回数 $\mathrm{n}$ の最大值 $\mathrm{N}$ は場所により 6,10 および23の 3 種類である。実験で見出された $\mathrm{N}$ と最終最大荷重に対する最終全沈下量W N との 間の一般的関係を示す曲線は第 3 図に示すとおり，Nが増すにしたがってW N の増加率は次第に減少 する傾向を示す。ここに最終全沈下量 $\mathrm{W}_{\mathrm{N}}$ は，初荷重を加える前の真砂体の表面のレベルから測った 沈下量である。

この場合最終全沈下量W N と N との間には

$$
\mathrm{W}_{\mathrm{N}}=\frac{\mathrm{N}}{\mathrm{a}+\mathrm{bN}}
$$

なる実験式 $\left.{ }^{4}\right)$ がよく成立つものとして広く採用されておるので, ここでもこの式を探用した。

ここに $\mathrm{a}, \mathrm{b}$ は定数である，第 $2^{*}$ 表中の定数 a ，bの值はここに添付してある第 1 表に示した $\mathrm{N}=$ 1,10 (および23）に対する実測值 $\mathrm{W}_{1}, \mathrm{~W}_{10}\left(\right.$ およ゙ $\mathrm{W}_{23}$ ）を用いて(15)式から見出されたものである。

次に, 初載荷実験の場合と同様な方法を用いて, 繰返し載荷実験の最終サイクルの加荷重過程にお ける荷重強度 $\mathrm{q} と \mathrm{~V}_{\mathrm{N}}$ から $\mu^{\prime}, \mathrm{B}$ を計算した（ $v_{\mathrm{N}}$ つ意味：Vー $(2)$ 繰返し載荷実験結果, 第 $\mathrm{a}$ 図参照 $)$ 。 これらを$\mu_{\mathrm{N}}^{\prime}, \mathrm{B}_{\mathrm{N}}$ と名づけよう。資料 $\mathrm{q}$ と $\mathrm{v}_{\mathrm{N}}$ の值は表一11〜表一14に示すとおりである。 
第 1 表 $W_{N}$ の測定值

\begin{tabular}{|c|c|c|c|c|c|c|c|}
\hline \multirow{2}{*}{ ルート } & \multirow{2}{*}{ 番号 } & \multicolumn{2}{|c|}{ 位 置 } & \multicolumn{2}{|c|}{$\mathrm{P}=0 \rightleftarrows 5$ ton } & \multicolumn{2}{|c|}{$P=0 \rightleftarrows 10$ ton } \\
\hline & & 脚 & E L & $\mathrm{N}$ & $\mathrm{W}_{\mathrm{N}}$ & $\mathrm{N}$ & $W_{N}$ \\
\hline \multirow{2}{*}{ 大久野島 } & \multirow{2}{*}{$\sqrt{2} 2$} & \multirow{2}{*}{$\mathrm{c}$} & \multirow{2}{*}{$\begin{array}{r}\mathrm{m} \\
0.97\end{array}$} & 1 & $0.62 \mathrm{~cm}$ & - & - \\
\hline & & & & 23 & 1.16 & - & - \\
\hline \multirow{2}{*}{ " } & \multirow{2}{*}{463} & \multirow{2}{*}{$\mathrm{a}$} & \multirow{2}{*}{4.01} & 1 & 0.43 & 1 & $0.67 \mathrm{~cm}$ \\
\hline & & & & 10 & 0.53 & 10 & 0.78 \\
\hline \multirow{2}{*}{ "I } & \multirow{2}{*}{ Na. 6} & \multirow{2}{*}{$\mathrm{c}$} & \multirow{2}{*}{6.52} & 1 & 0.25 & 1 & 0.44 \\
\hline & & & & 10 & 0.29 & 10 & 0.54 \\
\hline \multirow{2}{*}{ 来 島 } & \multirow{2}{*}{$\sqrt[N a]{ } 3$} & \multirow{2}{*}{ b } & \multirow{2}{*}{73.14} & 1 & 0.13 & 1 & 0.20 \\
\hline & & & & 10 & 0.165 & 10 & 0.22 \\
\hline
\end{tabular}

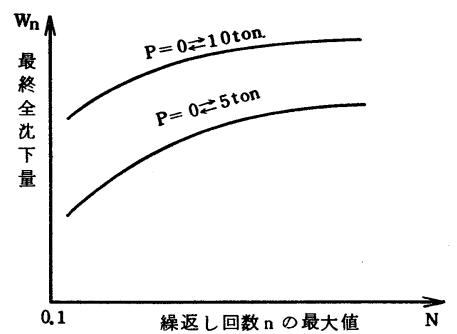

第 3 図 $W_{N}-N$ 関係（モデル）

$\mathrm{N}$ ：繰返し回数の最大值

$\mathrm{a} \mathrm{b}$ : 定数

$\mathrm{W}_{\mathrm{N}}: \mathrm{N}$ 回繰返し載荷の最終最大荷重に 対する沈全下量

1

$\frac{1}{b}=\mathrm{W} \infty$

\begin{tabular}{|c|c|c|c|c|c|c|c|c|c|c|c|c|c|c|c|c|c|}
\hline \multirow{2}{*}{\multicolumn{2}{|c|}{ 場 }} & \multirow[b]{2}{*}{ 所 } & \multirow{2}{*}{\begin{tabular}{|c|} 
E L \\
(m) \\
\end{tabular}} & \multicolumn{7}{|c|}{ 繰返藏荷実歌 $\mathrm{P}=0 \rightleftarrows 5$ ton } & \multicolumn{7}{|c|}{ 繰返 载 荷. 実 $P=0 \neq 10$ ton } \\
\hline & & & & $a(1 / \mathrm{cm})$ & $\mid b(1 / \mathrm{m} m \mid$ & 1) $1 / \mathrm{b}=\mathrm{W}_{\infty}(\mathrm{cm})$ & $\mathrm{W}_{\mathrm{N}}$ & N & $\mu_{\mathrm{Ni}}^{\prime}$ & $\mathrm{B}_{\left(\mathrm{kg} / \mathrm{cm}^{2}\right)}$ & $\mathrm{a}(1 / \mathrm{cm})$ & $\mathrm{b}(1 / \mathrm{cm})$ & $1 / \mathrm{b}=\mathrm{W}_{\infty}(\mathrm{cm})$ & $\mathrm{W}_{\mathrm{N}}$ & $\mathrm{N}$ & $\mu^{\prime} \mathrm{N}$ & $\mathrm{BN}_{N}\left(\mathrm{~kg} / \mathrm{m}^{2}\right)$ \\
\hline \multicolumn{3}{|c|}{ 大久野島ルート柏2 量铁塔c脚 } & 0.97 & 0.79 & 0.825 & 1.210 & 1.16 & 23 & 2.616 & 29.408 & - & - & - & - & 6 & 2.413 & 27.443 \\
\hline & " & 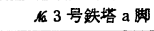 & 4.01 & 0.488 & 1.84 & 0.544 & 0.530 & 10 & 1.898 & 23.807 & 0.235 & 1.26 & 0.794 & 0.78 & 10 & 2,017 & \begin{tabular}{l|l|}
7 & 24.672 \\
\end{tabular} \\
\hline & " & 佁 6 号鉄呰 $\mathrm{c}$ 脚 & 6.52 & 0.58 & 3.42 & 0.292 & 0.290 & 10 & 1.467 & 20.835 & 0.468 & 1.80 & 0.556 & 0.54 & 10 & 1,601 & 21.709 \\
\hline 来 & 島 & 一下舟3 号鉄塔b 脚 & 73.14 & 1.81 & 5.88 & 0.170 & 0.165 & 10 & 1.624 & 22.915 & 0.50 & 4.50 & 0.223 & 0.22 & 10 & 1,709 & \begin{tabular}{|l|l|}
922.915 \\
\end{tabular} \\
\hline
\end{tabular}

第 3 表 初載荷実験

\begin{tabular}{|c|c|c|c|c|c|c|c|c|}
\hline \multirow{2}{*}{ 場 } & \multirow{2}{*}{ 所. } & E L & \multicolumn{3}{|c|}{ 初 } & 荷 & \multicolumn{2}{|l|}{ 験 } \\
\hline & & $(\mathrm{m})$ & $\mu^{\prime}$ & $\mathrm{B}\left(\mathrm{kg} / \mathrm{cm}^{2}\right)$ & Pの範囲 & $\mu^{\prime}$ & $B\left(\mathrm{~kg} / \mathrm{cm}^{2}\right)$ & Pの範囲 \\
\hline \multicolumn{2}{|c|}{ 大久野島ルート 胿 2 号鉄塔 $\mathrm{c}$ 脚 } & 1.97 & 1.50 & 20.64 & $1 \rightarrow 5$ ton & 0.99 & 17.55 & $5 \rightarrow 16$ ton \\
\hline " & 伯 3 号鉄塔 a 脚 & 5.01 & - & - & - & 1.20 & 18.84 & $1 \rightarrow 16$ ton \\
\hline$"$ & 版 6 号鉄塔 $\mathrm{c}$ 脚 & 7.52 & - & - & - & 1.56 & 21.34 & $1 \rightarrow 16$ ton \\
\hline 来島ルート & 号鉄塔 & 74.14 & - & - & - & 1.49 & 21.08 & $1 \rightarrow 16$ ton \\
\hline
\end{tabular}

上記の $\mathrm{a}, \mathrm{b}, 1 / \mathrm{b}(=\mathrm{W} \infty), \mu^{\prime} \mathrm{N}, \mathrm{BN}$ 等の值は一括してここに添付してある第 2 表に示

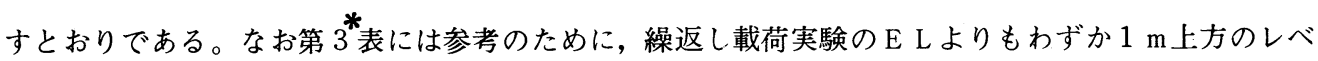
ルですでに行なわれた初載荷実験の $\mu^{\prime}$ と Bの值を示しておいた。 
まず、 2 表の $1 / \mathrm{b}=\mathrm{W} \infty$ と E L との関係を図示したここに添付の第 4 罒をみると, $\mathrm{P}=0 \rightleftarrows 5$ ton の場合と $\mathrm{P}=0 \rightleftarrows 10$ ton の場合とは、よく似ていることが注目される。

すなわち, $\mathrm{W}_{\infty}$ と E L との関係は, $\mathrm{C}_{1}, \mathrm{C}_{2}$, を定数とすれば

$$
\left(\mathrm{W}_{\infty}-\mathrm{C}_{1}\right) \cdot \mathrm{E} \mathrm{L}=\mathrm{C}_{2}
$$

なる直角双曲線で近似できるようにみえる。ここに定数 $\mathrm{C}_{1}, \mathrm{C}_{2}$ は繰返し載荷の最終最大荷重の大きさ に関係すると想像される。ここに述べられた事柄は数 少ない資料から得られたものであるが，きわめて重要 なことであると思われるので, 将来さらに研究を積む ことが希望される。

次に, 第 2 表の第 6 欄の最終サイクルの測定値W N と第 5 欄の計算值 $\mathrm{W}_{\infty}$ から， $\left(\mathrm{W}_{\infty}-\mathrm{W}_{\mathrm{N}}\right) / \mathrm{W}_{\infty}$ の 比を求めると $\mathrm{E} \mathrm{L}=0.97,4.01,6.52,73.14 \mathrm{~m}$ の順 にそれぞれ $4.1 \% ， 2.6 \% ， 6.8 \% ， 2.9 \%$ ある。 すなわち,それぞれ $\mathrm{N}=23,10,10,10$,で $\mathrm{W}_{\mathrm{N}}$ はわずか 3 \%ないし $7 \%$ 差でW $W_{\infty}$ に接近しておることがわかる。 次に, 第 2 表中の $\mu^{\prime}{ }_{\mathrm{N}}$ と $\mathrm{B}_{\mathrm{N}}$ の值を図示したものは 第.5図である。この図に表現されている直線関係は略 算によると,すなわち

$$
\begin{aligned}
& \mu_{\mathrm{N}}^{\prime}=-1.40+0.138 \mathrm{~B}_{\mathrm{N}} \\
& \mu_{\mathrm{N}}^{\prime}=0.138\left(\mathrm{~B}_{\mathrm{N}}-10.1\right)
\end{aligned}
$$

である。(17.2)式をさきに見出されている初載荷実 験で得られた(10)式 $\left.\mu^{\prime}=0.136 （ \mathrm{~B}-10.0\right)$ と比較する と, 両式の係数の值は驚くべき一致を示している。た だしここに注意を要することは，(17.2）式を与え た繰返し載荷実験の E L は，第 $2^{*}$ 表と第 3 表とをみる とわかるとおり(10)式を与えた初載荷実験の E Lより 1 $\mathrm{m}$ 小さいことである。詳しくいえば，最終レベルでの 初載荷実験を終えた後, 表面を $1 \mathrm{~m}$ 掘下げて得た新し い表面に対して繰返し載荷実験を行なったのである。 しかし上記の両式の係数の值の一致は, E L の $1 \mathrm{~m} の$ 相違を無視せしめるほどの警くべき一致である。

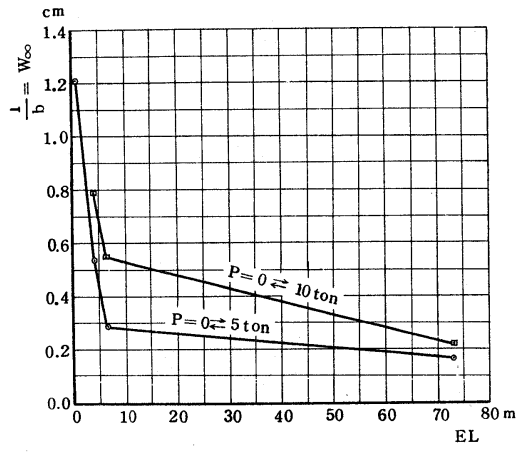

第 4 図 繰返し載荷実験 $b=E L$ 関係

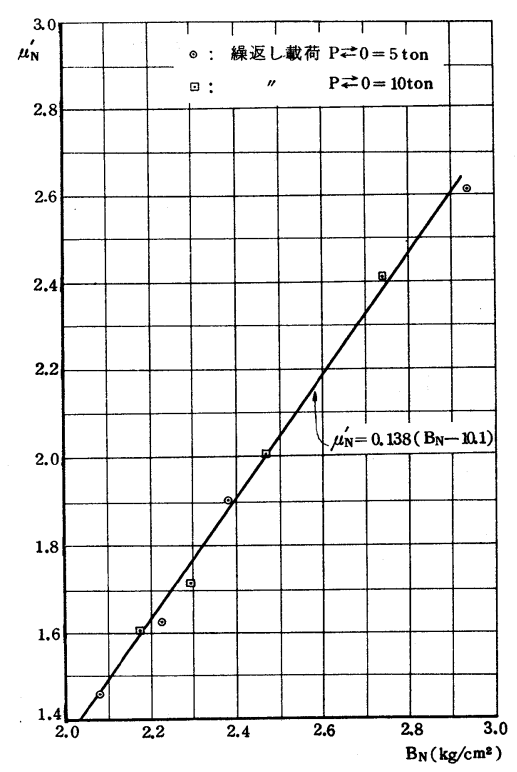

第 5 図 䆆返し載荷実験最終サイクルの加荷重 過程における， $\mu_{\mathrm{N}}^{\prime}$ と $\mathrm{B}_{\mathrm{N}}$ との関係

さて，上記の両式を得た資料の変化する範囲をみると， $\left(\mu_{\mathrm{N}}^{\prime}, \mathrm{B}_{\mathrm{N}}\right)$ の範囲は， $(1.467,20.835)$ $\sim(2.616,29.408)$ 〔表一15]，( $\mu^{\prime}$, B $)$ の範囲は $(0.55,14.75) \sim(1.56,21.34)$ 〔表一 5 〕 
である，上記の範囲と両式を図示したものは第6 6図である。この図をみると 2 本の直線の違いはきわ めてわずかである。したがって，初載荷実験の場合の $\mu^{\prime} ， \mathrm{~B}$ の資料と繰返し載荷実験最終サイクルの 場合の $\mu_{\mathrm{N}} ， \mathrm{~B}_{\mathrm{N}}$ の資料を一括して最小自乗法により新しく $\mu^{\prime}$ と B との間の直線関係を決定すること ができる。第 6 図の太線 $\mathrm{c} \mathrm{d}$ および e $\mathrm{f}$ は，それぞれ $\mu^{\prime}, \mathrm{B}$ 資料および $\mu_{\mathrm{N}}^{\prime}, \mathrm{B}_{\mathrm{N}}$ 資料の分布範囲を 示す直線である。

したがって，瀬戸内花崗岩の真砂体のある任意の E Lにおいて，初載荷実験と繰返し載荷実験を行 なった場合は，後者の最終サイクルにおいて見出される $\mu_{\mathrm{N}}^{\prime}, \mathrm{B}_{\mathrm{N}}$ の值は，前者の $\mu^{\prime}-\mathrm{B} の$ 関係を 示す直線を$\mu^{\prime}$ の増加する方向に延長した線上に現われるということが，第6図によって明かにされて いる。この事実は 4 か所にわたる真砂体全体の特性の一つであるといえよう。

次に，第 $2^{*}$ 表と第 $3^{*}$ 表に示された $\mu_{\mathrm{N}}^{\prime}$ と $\mu^{\prime}$ の值の比 較を試みてみよう。 $\mu_{\mathrm{N}}^{\prime}$ の值は $\mathrm{P}=0 \rightleftarrows 5$ ton と $\mathrm{P}=$ $0 \rightleftarrows 10$ ton 92 とおりに対してそれぞれ見出されてお ク，これに対し $\mu^{\prime}$ の值は $\mathrm{P}=1 \rightarrow 5$ tonと $\mathrm{P}=1$ （また は 5$) \rightarrow 16$ tonつ 2 とおりに対して見出されているが, 4 か所の全基礎地盤のすべてに対して $\mu^{\prime}$ が見出されて いるのは $\mathrm{P}=1$ （または 5 ）－16tonの場合だけである。

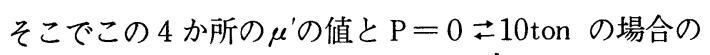
4 が所の $\mu_{\mathrm{N}}^{\prime}$ 值を比較してみると第7図のようになる。 この図の 4 か所の点の配列は直線で近似できるので, 最小自乗法によって計算した結果は

$$
\begin{aligned}
\mu_{\mathrm{N}}^{\prime} & =3.725-1.367 \mu^{\prime} \\
& \pm 0.139 \text { (M. E.) } \pm 0.104 \text { (M.E. ) (18) }
\end{aligned}
$$

である。こ>にM. E. は平均自乗䛊差 (meanerror) を示す。(18)式から次に述べるような興味あることが見 出される。いま, こ、に

$$
\frac{\mu_{N}^{\prime}}{\mu^{\prime}}=\gamma
$$

なる $\gamma$ を導入すると(18)式から

$$
\gamma=\frac{3.725}{\mu^{\prime}}-1.367
$$

を得る。(20)式から

$$
\mu^{\prime} \lesseqgtr 1.574 \text { に対して } \gamma=\frac{\mu_{\mathrm{N}}^{\prime}}{\mu^{\prime}} \gtreqless 1
$$

すなわち, $\mu_{N}^{\prime} \gtreqless \mu^{\prime} \quad$ (21) が得られる。

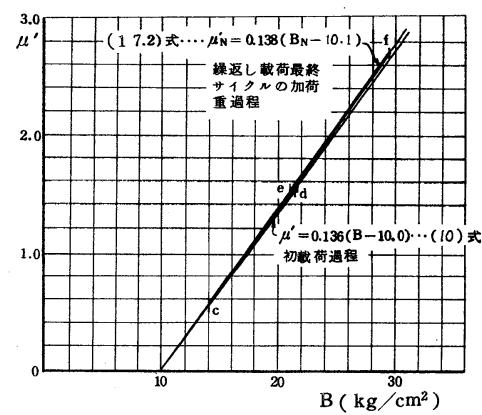

第 6 図初載荷過程における $\mu$ - B 関係と繰 返し載荷最終サイクルの加荷重過程 における， $\mu_{\mathrm{N}}^{\prime}-\mathrm{B}_{\mathrm{N}}$ との比較

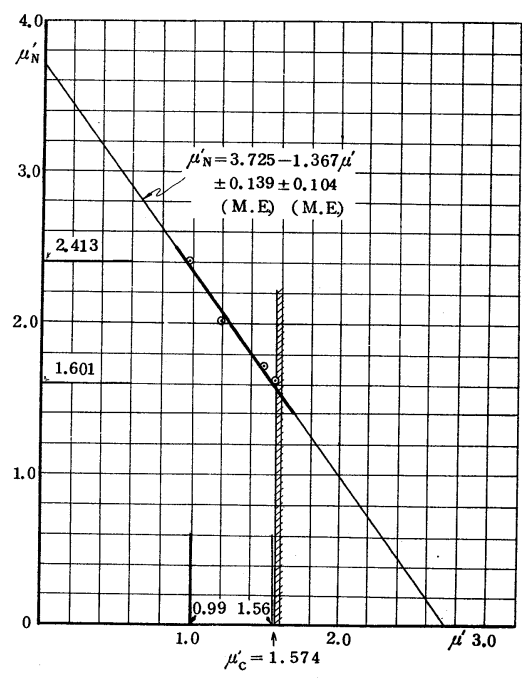

第 7 図

$\mu_{\mathrm{N}}^{\prime}$ との関係

$\mu_{N}^{\prime} ; P(0 \rightleftarrows 10$ ton) $)$ に対して見出された $\mu^{\prime} ; \mathrm{P}$ (1 $1 \rightarrow 16$ ton $)$ " 
(21)式の示すように初載荷における見掛歪硬化指数の特定值 $\mu^{\prime}=1.574$ に対して $\gamma=1$ となり $\mu_{N}{ }_{N}=$ $\mu^{\prime}=1.574$ となる。このような $\mu^{\prime}$ の特定值を $\mu^{\prime}{ }_{\mathrm{c}}$ で示し, これを臨界見掛歪硬化指数 (critical apparent strain hardening exponent) と名命しよう。 $\mu_{c}^{\prime}$ を $\mu_{N}^{\prime}=\alpha+\beta \mu^{\prime}$ なる直線式における $\alpha, \beta$ で表現 するならば $\mu^{\prime}{ }_{c}=\alpha /(1-\beta)$ である。 $\mu^{\prime}{ }_{c}=1.574$ なる臨界見掛歪硬化指数の值は, 瀬戸内花崗岩 の真砂体の特性定数の一つとみることができると思う。

(21)式の相対応する二つの不等式から次のことがいえる。すなわち, 瀬戸内花崗岩の真砂体のあるレ ベルの自由表面で行なわれた初載荷実験で見出された $\mu^{\prime}$ の值が臨界值 $\mu_{c}^{\prime}=1.574$ よりも小さい場合に

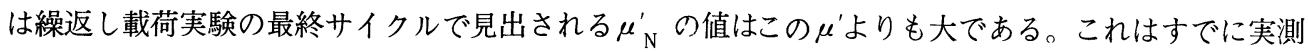
より確認されており，第 $2^{*}$ 表の $\mathrm{P}=0 \geq 10$ ton に対する $\mu_{\mathrm{N}}^{\prime}$ と, 第3*表の $\mathrm{P}=1$ および $5 \rightarrow 16$ ton に対する $\mu^{\prime}$ の比較が示すとおりである。 4 か所の鉄塔基礎地盤について見出された $\mu^{\prime}$ 最大值は第 $3^{*}$

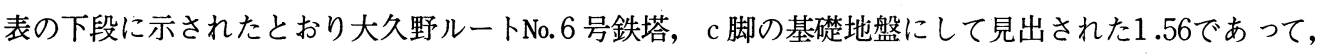
これは $\mu_{c}^{\prime}=1.574$ よりわずか $1 \%$ 小さい值である。

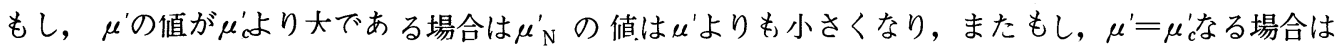
は $\mu_{N}^{\prime}=\mu_{c}^{\prime}$ ることが予想される。しかしこれは実際には見出されてはいない。

$\mu_{N}^{\prime}$ と $\mu^{\prime}$ の関係について得られた上記の結論は重要と思われるので, 瀬戸内地域の他の場所および 瀬戸内以外の地域の花崗岩の風化体に対して，同様の検討が行なわれることが希望される。

\section{7. 結 語}

中四幹線海峡部横断高鉄塔，大久野島ルートNo. 2 号鉄塔， c 脚 (大三島)，同 No. 3 号鉄塔， a 脚（大 久野島）, 同No.6 号鉄塔， c 脚（忠海）および来島ルートNo. 3 号鉄塔， b 脚（馬島）の基礎地盤を構 成する瀬戸内花崗岩の風化体である真砂体の外力に対する変形特性を調らべるために，場所および深 度別に現地載荷実験ならびに鉄塔基礎床付予定地盤において繰返し載荷実験を実施した。

その結果に対して解析を行なって得られた結論を要約すると次のとおりである。

-1) 荷重強度 $\mathrm{q}$ 一沈下量 $\mathrm{w}$ 関係の比例法則と応力一歪関係の指数法則とを組み合せて次式を導いた。

$$
\mathrm{q}=\mathrm{B}\left(\frac{\mathrm{w}}{1.5 \mathrm{a}}\right) \mu^{\prime}
$$

この式は上記の 4 か所の鉄塔基礎地盤の真砂体の表面で見出された $\mathrm{q}-\mathrm{w}$ 関係の非直線性をよく説 明する経験式である。上式で $\mathrm{B}$ は応力と同次元の定数， $\mu^{\prime}$ は無次元の定数 $\mathrm{a}$ は加圧板の半径であ る。定数 $\mu^{\prime}$ 見掛歪硬化指数と名づけた。指数 $\mu^{\prime} は$ 次の如き意味をもつものである。すなわち， $\mu$ $>1$ である場合は，荷重が増加するにしたがって物質は次第に硬くなり， $\mu^{\prime}<1$ の場合には反対に 軟くなるような現象を示す。 $\mu^{\prime}=1$ の場合には硬さの変化は現われない。

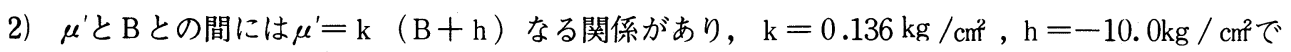
ある。これは今後 $\mu^{\prime} の$ 物理的意味を研究するのに重要な手がかりになると思われる。 


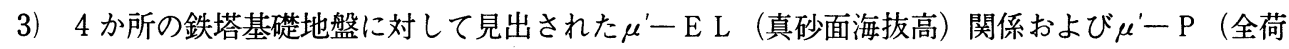

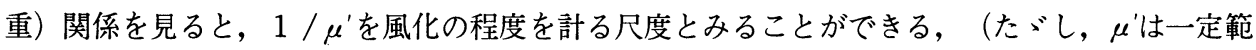
囲の荷重に対して規定されなければならないものである）。これは将来何かある方法によって風 化度を定量化し，これと的との関係を研究するという新しいテーマを提供する。これはまた $\mu^{\prime} の$ 物理的意味を明かにする道を開くものと思われる。

4）荷重一沈下量曲線の各部において計算された接線見掛ヤング率と割線見掛ヤング率が $\mathrm{E} \mathrm{L} \mathrm{およ}$ び $\mathrm{P}$ に対して 翟化する模様をみるときわめて不規則であると考えられる。このことは真砂体を 巨視的にみて定数 $\mu^{\prime} か ゙$ 決定されたことと対照的である。

5） 全荷重 $\mathrm{P}=0 \rightleftarrows 5$ tonおよび $\mathrm{P}=0 \rightleftarrows 10$ tonの範囲で行なわれた繰返し載荷実験の最終サイクル の回数 $\mathrm{N} （ 10 \sim 23)$ と，それに対する最終全沈下量 $\mathrm{W}_{\mathrm{N}}$ との関係を示す $\mathrm{W}_{\mathrm{N}}=\mathrm{N} /(\mathrm{a}+\mathrm{N} \mathrm{b})$ なる実験式の定数 a ， b （=1/ $\mathrm{W}_{\infty} ）$ の值を 4 か所の鉄塔基礎地盤面で見出した。そして $1 / \mathrm{b}$ $=\mathrm{W}_{\infty}$ と E L との関係は直角双曲線で近似できることもわかった。このことは数少ない資料から 得られたものであるが, きわめて重要な事柄と思われるので, 将来さらに研究を積むことが希望される。

6）初載荷実験における $\mu^{\prime}-\mathrm{B}$ 関係と繰返し載荷実験の最終サイクルにおける $\mu^{\prime}{ }_{\mathrm{N}}-\mathrm{B}_{\mathrm{N}}$ との関係 を比較すると，後者は前者の $\mu^{\prime}$ の増加する方向への延長線の上に現われる。このことは当地方の 真砂体のもう一つの特性であるといえよう。

7） $\mu^{\prime}$ と $\mu^{\prime}{ }_{\mathrm{N}}$ との関係を含味すると， $\mu_{c}^{\prime}=1.574$ なる臨界見掛歪硬化指数が見出された。 $\mu^{\prime}{ }_{c}$ の意味 は $\mu^{\prime} \lesseqgtr \mu_{c}^{\prime}$ に対して $\mu_{\mathrm{N}}^{\prime} \gtreqless \mu^{\prime}$ が成立することである。このように見掛歪硬化指数に 1.547 なる臨界 值が存在するということは, 当地域の瀬戸内花崗岩の真砂体の興味ある特徵である。したがって, 瀬戸内地域の他の場所の真砂体および瀬戸内以外の地域の真砂体に対して同様の検討が行なわれ ることが希望される。

8）以上の結論は広島県竹原市一愛媛県今治市間の 1 本のルートに沿う真砂体について得られたも のである。したがって，瀬戸内地域の他の場所および瀬戸内以外の地域の真砂体に対して同様の 検討のなされることが希望される。

\section{謝辞}

本論文の作成にあたり，京都大学熊谷直一名誉教授，同初田甚一郎教授の御媳篤な御指導，同村山 朔郎教授の現地御指導をいだ゙いた，さらに本調査の機会を与えられ、本論文完成に至るまで終始御愳切 な御教示をいだ゙いた電源開発株式会社広田孝一技術顧問の方々に対して心から厚く感謝の辞を捧 げる。なおまた, 調查・研究にさいしては広島大学梅垣嘉治教授, 東京大学南雲照三郎助教授には有 益な御助言を与えられた，ここに深く感謝の意を表する。

電源開発株式会社中四幹線建設所林潔所長，同島田潔課長代理ほか関係各位から現場実験開始以来 数年にわたりなみなみなら御協力を得た，併せて厚く感謝の辞を呈する。 


\section{参考文献}

1) Società Generale Elettrica della Sicilia

L'ATTRAVERSAMENTO Elettrico Dello Stret to di Messina

Libreria DEDALO editrice , Roma , via Barberini 75

2) ソコロフスキー, ブェー, ブェー, 塑性理論 第 2 版（大橋義夫訳, 朝倉書店1950)

Sokolovsky , V , V . , Some discontinuous solution in soil mechanics

Neuvième congrés internationale de mećanique appliquée

$$
\text { (Brussel , T . 8, 1957) }
$$

Holloman , J . H . , Melals Technology , 12, No.4 (1945)

南雲昭三郎, 岩石の変形に関する力学理論について

第 3 回岩盤力学に関するシンポジウム，P . 67〜68（土木学会岩盤力学委員会1965）

3) Boussinesq , J. ,“ Application des potentiels ..............”, (Paris , 1885)

Timoshenko and Goodier, Theory of Elasticity, 2 nd Ed , P . 372 (1951)

Sneddon , Ian , N. ,Indentation by a flat - ended cylinder , P .458

International series in pure and applied mathematics

-Fourier Transform - (McGraw Hill Co . 1951)

4）佐々木次郎, 締固め工法の研究, 農業技術研究所報告 F, No.

5）大西千秋, 中四連絡送電線鉄塔基礎上引耐力試験の概要, 応用地質, Vol.2, No.1 p. - 10, 1961年 5 月 
表ー1 初載荷実験における荷重に 対する沈下量 $\mathrm{w}$ の測定値

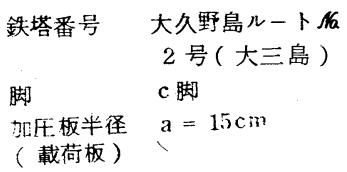

\begin{tabular}{|c|c|c|c|c|}
\hline 荷 & 重 & $E L=7.47(\mathrm{~m})$ & $E \mathrm{~L}=4.47(\mathrm{~m})$ & $E \mathrm{~L}=1.97(\mathrm{~m})$ \\
\hline 全荷重 P & 荷重強度 q & 沈下量 $w$ & 沈下量 $\mathbf{w}$ & 观下量 $w$ \\
\hline$t$ & $\mathrm{~kg} / \mathrm{cm}^{2}$ & $\mathrm{~cm}$ & $\mathrm{~cm}$ & $\mathrm{~cm}$ \\
\hline 1 & 1.414 & 0.351 & 0.203 . & 0.237 \\
\hline 2 & 2.829 & 0.620 & 0.330 & 0.335 \\
\hline 3 & 4.243 & 0.944 & 0.464 & 0.427 \\
\hline 4 & 5.658 & 1.347 & 0.640 & 0.529 \\
\hline 5 & 7.072 & 1.801 & 0.829 & 0.616 \\
\hline 6 & 8.487 & & 1.029 & 0.735 \\
\hline 7 & 9.901 & & 1.224 & 0.834 \\
\hline 8 & 11.315 & & 1.452 & 0.963 \\
\hline 9 & 12.730 & & 1.678 & 1.093 \\
\hline 10 & 14.144 & & 1.875 & 1.193 \\
\hline 11 & 15.559 & & & 1.283 \\
\hline 12 & 16.973 & & & 1.428 \\
\hline 13 & 18.388 & & & 1.557 \\
\hline 14 & 19.802 & & & 1.683 \\
\hline 15 & 21.216 & & & 1.803 \\
\hline 16 & 22.631 & & & 1.923 \\
\hline
\end{tabular}

表一 3 初載荷実験における荷重 に対する沈下量 $\mathrm{w}$ 測定值

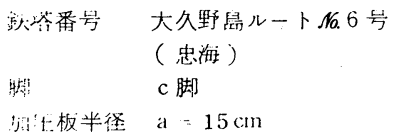

jis: t板半惩 $a=15 \mathrm{~cm}$

\begin{tabular}{|c|c|c|c|}
\hline 荷 & 重 & $\mathrm{E} \mathrm{L}=12.22(\mathrm{~m})$ & $\mathrm{EL}=7.52(\mathrm{~m})$ \\
\hline 金重 $\mathrm{P}$ & 荷重強度 $\mathrm{q}$ & 沈 下 量 $\mathrm{w}$ & 沈 下 量 $\mathrm{w}$ \\
\hline $\mathrm{t}$ & $\mathrm{kg} / \mathrm{cm}^{2}$ & $\mathrm{~cm}$ & $\mathrm{~cm}$ \\
\hline 0.5 & 0.707 & 0.104 & \\
1 & 1.414 & 0.157 & 0.078 \\
2 & 2.829 & 0.269 & 0.127 \\
3 & 4.243 & 0.374 & 0.175 \\
4 & 5.658 & 0.486 & 0.216 \\
5 & 7.072 & 0.599 & 0.255 \\
6 & 8.487 & 0.732 & 0.292 \\
7 & 9.901 & 0.864 & 0.327 \\
8 & 11.315 & 0.986 & 0.365 \\
9 & 12.730 & 1.127 & 0.401 \\
10 & 14.144 & 1.257 & 0.439 \\
11 & 15.559 & 1.372 & 0.486 \\
12 & 16.973 & 1.505 & 0.522 \\
13 & 18.388 & & 0.560 \\
14 & 19.802 & 1.741 & 0.604 \\
15 & 21.216 & & 0.636 \\
16 & 22.631 & 1.901 & 0.675 \\
\hline
\end{tabular}

表一 2 初載荷実験における荷重に 対する沈下量 wの測定值

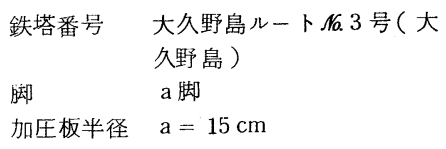

\begin{tabular}{|c|c|c|c|}
\hline 荷 & 重 & $E L=8.31(\mathrm{~m})$ & $\mathrm{EL}=5.01(\mathrm{~m})$ \\
\hline 全獄重 P & 荷重強度 q & 沈下量 w & 沈下量 w \\
\hline $\mathrm{t}$ & $\mathrm{kg} / \mathrm{cm}^{2}$ & $\mathrm{~cm}$ & $\mathrm{~cm}$ \\
\hline 1 & 1.414 & & 0.100 \\
\hline 2 & 2.829 & 0.187 & 0.188 \\
\hline 3 & 4.243 & & 0.259 \\
\hline 4 & 5.658 & 0.303 & 0.331 \\
\hline 5 & 7.072 & & 0.394 \\
\hline 6 & 8.487 & 0.411 & 0.453 \\
\hline 7 & 9.901 & & 0.511 \\
\hline 8 & 11.315 & 0.524 & 0.563 \\
\hline 9 & 12.730 & & 0.626 \\
\hline 10 & 14.144 & 0.657 & 0.679 \\
\hline 11 & 15.559 & & 0.751 \\
\hline 12 & 16.973 & 0.821 & 0.809 \\
\hline 13 & 18.388 & & 0.869 \\
\hline 14 & 19.802 & 1.015 & 0.924 \\
\hline 15 & 21.216 & & 0.991 \\
\hline 16 & 22.631 & 1.220 & 1.041 \\
\hline
\end{tabular}

\section{表一 4 初載荷実験における荷重} に対する沈下 $\mathrm{w}$ の測定值

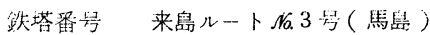

$$
\begin{aligned}
& \text { 脚 } \quad \mathrm{b} \text { 脚 } \\
& \text { 加里板半径 } \quad a=15 \mathrm{~cm}
\end{aligned}
$$

\begin{tabular}{|c|c|c|c|}
\hline \multicolumn{1}{|c|}{ 荷 } & 重 & $\mathrm{EL}=74.64(\mathrm{~m})$ & $\mathrm{EL}=74.14 \mathrm{~m})$ \\
\hline 全街重 $\mathrm{p}$ & 何重强度 $\mathrm{q}$ & 沈 下 量 $\mathrm{w}$ & 沈 下 量 $\mathrm{w}$ \\
\hline $\mathrm{t}$ & $\mathrm{kg} / \mathrm{cm}^{2}$ & $\mathrm{~cm}$ & $\mathrm{~cm}$ \\
\hline 1 & 1.414 & 0.184 & 0.036 \\
2 & 2.829 & 0.302 & 0.060 \\
3 & 4.243 & 0.437 & 0.089 \\
4 & 5.658 & 0.582 & 0.113 \\
5 & 7.072 & 0.725 & 0.132 \\
6 & 8.487 & 0.864 & 0.148 \\
7 & 9.901 & 1.002 & 0.155 \\
8 & 11.315 & 1.165 & 0.168 \\
9 & 12.730 & 1.350 & 0.183 \\
10 & 14.144 & 1.604 & 0.196 \\
11 & 15.659 & 1.851 & 0.207 \\
12 & 16.973 & 2.289 & 0.226 \\
13 & 18.388 & & 0.235 \\
14 & 19.802 & & 0.247 \\
15 & 21.216 & & 0.256 \\
16 & 22.631 & & 0.256 \\
\hline
\end{tabular}


表一 $5 \quad \mu$ および $\mathrm{B}$ の值

\begin{tabular}{|c|c|c|c|c|c|c|c|c|}
\hline 鉄 塔 番 号 & 脚 & $E L(m)$ & $\mathrm{P}$ の範讲( $\mathrm{t}$ ) & 折点 $(t)$ & $\mu^{\prime}<0.9$ & $\begin{array}{r}\mu^{\prime} \\
\mu^{\prime} \doteqdot 1 \\
\end{array}$ & $\mu^{\prime}>1.1$ & $\mathrm{~B}\left(\mathrm{~kg} / \mathrm{cm}^{2}\right)$ \\
\hline \multirow{2}{*}{ 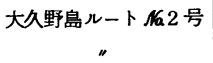 } & c & 7.47 & $3 \geq P \geq 1$ & \multirow{2}{*}{3} & & \multirow[t]{2}{*}{0.96} & & 15.68 \\
\hline & $"$ & $"$ & $5 \geq P \geq 3$ & & 0.76 & & & 14.75 \\
\hline " & " & 4.47 & $3 \geq P \geq 1$ & \multirow{2}{*}{3} & \multirow[b]{2}{*}{0.85} & & \multirow{2}{*}{1.19} & 18.66 \\
\hline " & " & " & $10 \geq P \geq 3$ & & & & & 16.10 \\
\hline " & " & 1.97 & $5 \geq P \geq 1$ & \multirow{2}{*}{5} & & \multirow[b]{2}{*}{0.99} & \multirow[t]{2}{*}{1.50} & 20.64 \\
\hline " & $"$ & " & $16 \geq P \geq 5$ & & & & & 17.55 \\
\hline \multirow{3}{*}{$\begin{array}{c}\text { 大久野島ルートNa. } 3 \text { 号 } \\
\prime \prime\end{array}$} & $\mathbf{a}$ & 8.31 & $10 \geq P \geq 2$ & \multirow{2}{*}{8.8} & & & \multirow[t]{2}{*}{1.27} & 19.28 \\
\hline & $"$ & $\prime \prime$ & $16 \geq P \geq 10$ & & 0.76 & & & 16.44 \\
\hline & $"$ & 5.01 & $16 \geq P \geq 1$ & & & & 1.20 & 18.84 \\
\hline \multirow{3}{*}{$\begin{array}{c}\text { 大久野島ルートNa } 6 \text { 号 } \\
\text { " }\end{array}$} & $\mathrm{c}$ & 12.22 & $3 \geq P \geq 1$ & \multirow{2}{*}{3} & & \multirow{3}{*}{1.01} & \multirow[t]{2}{*}{1.27} & 19.19 \\
\hline & " & " & $16 \geq P \geq 3$ & & & & & 17.65 \\
\hline & $" \prime$ & 7.52 & $16 \geq P \geq 1$ & & & & 1.56 & 21.34 \\
\hline \multirow{3}{*}{ 来島ルートNa 3 号 } & $\mathrm{b}$ & 74.64 & $8 \geq P \geq 1$ & \multirow{2}{*}{8.5} & & \multirow[t]{2}{*}{1.03} & & 17.29 \\
\hline & " & " & $12 \geq P \geq 9$ & & 0.55 & & & 15.28 \\
\hline & " & 74.14 & $16 \geq P \geq 1$ & & & & 1.49 & 21.08 \\
\hline
\end{tabular}

表一 $6 \mathrm{E}^{\prime}$ 割線 $\cdot \mathrm{E}^{\prime}$ 接線 $-\mathrm{EL}$ 関係

\begin{tabular}{|c|c|c|c|c|c|}
\hline 鉄 塔 番 号 & 脚 & $\mathrm{E} \mathrm{L}(\mathrm{m})$ & 全荷重 $\mathrm{P}(\mathrm{t})$ & $\mathrm{E}_{\text {割線 }}^{\prime}\left(\mathrm{kg} / \mathrm{cm}^{2}\right)$ & $\mathrm{E}_{\text {接線 }\left(\mathrm{kg} / \mathrm{cm}^{2}\right)}$ \\
\hline 大久野島ルートNa. 2 号 & c & 7.47 & 5 & 88.38 & 67.17 \\
\hline " & $"$ & 4.47 & " & 176.75 & 150.25 \\
\hline$"$ & $"$ & 1.97 & " & 265.13 & 262.47 \\
\hline " & " & 4.47 & 10 & 163.13 & 138.68 \\
\hline$"$ & 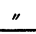 & 1.97 & $"$ & 265.13 & 262.47 \\
\hline 大久野島ルートNa3 号 & $\mathrm{a}$ & 8.31 & 6 & 424.50 & 539.12 \\
\hline " & " & 5.01 & " & 424.50 & 509.40 \\
\hline " & " & $"$ & 5 & 353.51 & 424.20 \\
\hline " & $"$ & 8.31 & 10 & 530.25 & 402.99 \\
\hline " & $"$ & 5.01 & " & 424.20 & 509.04 \\
\hline 大久野島ルートNa 6 号 & c & 12.22 & 5 & 265.13 & 267.78 \\
\hline " & " & 7.52 & $"$ & 530.25 & 827.19 \\
\hline$"$ & " & 12.22 & 10 & 265.13 & 267.78 \\
\hline$"$ & $"$ & 7.52 & $"$ & 707.00 & 1102.91 \\
\hline 来島ルートNa.3 号 & $\mathrm{b}$ & 74.64 & 5 & 212.10 & 218.46 \\
\hline & " & 74.14 & $"$ & 1178.33 & 1755.71 \\
\hline & $"$ & 74.64 & 10 & 192.83 & 160.05 \\
\hline & " & 74.14 & $"$ & 2121.00 & 3160.29 \\
\hline
\end{tabular}

表一7 $\mathrm{E} L$ 別にみた $\mathrm{E}^{\prime}{ }_{\text {割線 }} \mathrm{E}^{\prime}$ 接線一全荷重 $\mathrm{P}$ 関係

\begin{tabular}{|c|c|c|c|c|c|}
\hline 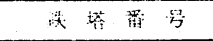 & 脚 & $\mathrm{E} L(\mathrm{~m})$ & 全荷重 $\mathrm{P}(\mathrm{t})$ & $\mathrm{E}_{\text {割線 }}^{\prime}\left(\mathrm{kg} / \mathrm{cm}^{2}\right)$ & 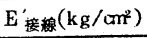 \\
\hline 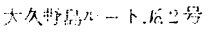 & c & $\bar{i} .47$ & 1 & 105.75 & 101.52 \\
\hline 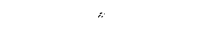 & $"$ & r & 2 & 106.13 & 101.88 \\
\hline$"$ & " & " & 3 & 106.01 & 101.76 \\
\hline$"$ & " & " & 4 & 94.34 & 71.70 \\
\hline$"$ & $"$ & $"$ & 5 & 83.38 & 67.17 \\
\hline " & " & 4.47 & 2 & 212.25 & 252.57 \\
\hline$r$ & $"$ & " & 4 & 212.25 & 180.42 \\
\hline " & $"$ & " & 6 & 181.94 & 154.65 \\
\hline " & " & " & 8 & 169.80 & 144.33 \\
\hline$"$ & $"$ & $"$ & 10 & 163.13 & 138.68 \\
\hline$"$ & $"$ & 1.97 & 2 & 212.25 & 318.38 \\
\hline " & $"$ & $"$ & 4 & 252.25 & 318.38 \\
\hline " & $"$ & $"$ & 6 & 254.78 & 252.00 \\
\hline " & " & " & 8 & 283.01 & 280.17 \\
\hline " & $"$ & " & 10 & 265.13 & 262.47 \\
\hline$"$ & " & $"$ & 12 & 282.84 & 280.01 \\
\hline " & $"$ & " & 14 & 270.00 & 267.30 \\
\hline " & $"$ & " & 16 & 261.12 & 258.51 \\
\hline
\end{tabular}


表一8 $\mathrm{E} L$ 別にみた $\mathrm{E}^{\prime}$ 割線・ $^{\prime} \mathrm{E}^{\prime}$ 接線一全荷重 $\mathrm{P}$ 関係（続き）

\begin{tabular}{|c|c|c|c|c|c|}
\hline 鉄㟷类奇 & 脚 & $\mathrm{FL}_{\mathrm{L}}(\mathrm{m})$ & 全荷重 $\mathrm{P}(\mathrm{t})$ & $\mathrm{E}_{\text {制線 }}\left(\mathrm{kg} / \mathrm{cm}^{2}\right)$ & $E_{\text {接楾 }}^{\prime}\left(\mathrm{kg} / \mathrm{cm}^{2}\right)$ \\
\hline 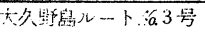 & $\mathrm{a}$ & 8.31 & 2 & 424.50 & 539.12 \\
\hline " & $"$ & " & 4 & 424.50 & 539.12 \\
\hline " & $"$ & " & 6 & 424.50 & 539.12 \\
\hline$\because$ & $"$ & " & 8 & 566.00 & 718.82 \\
\hline " & $"$ & " & 10 & 530.25 & 402.99 \\
\hline " & $"$ & " & 12 & 509.10 & 386.91 \\
\hline " & $"$ & " & 14 & 424.29 & 322.46 \\
\hline " & " & $"$ & 16 & 484.94 & $368.5 \overline{5}$ \\
\hline " & " & 5.01 & 2 & 424.50 & 494.40 \\
\hline " & " & " & 4 & 424.50 & 494.40 \\
\hline " & " & $"$ & 6 & 424.50 & 494.40 \\
\hline " & " & " & 8 & 424.50 & 494.40 \\
\hline " & " & " & 10 & 424.20 & 509.04 \\
\hline " & " & " & 12 & 509.10 & 610.92 \\
\hline " & " & " & 14 & 495.00 & 594.00 \\
\hline 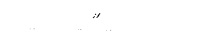 & $"$ & " & 16 & 484.94 & 581.93 \\
\hline
\end{tabular}

\section{表一 $9 E L$ 別にみた $E^{\prime}$ 割線 $E^{\prime}$ 接線一全荷重 $\mathrm{P}$ 関係（続き）}

\begin{tabular}{|c|c|c|c|c|c|}
\hline 鉄塔 番 号 & 却 & $E L(m)$ & 全荷重 $P(t)$ & 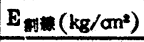 & 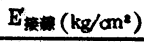 \\
\hline 大久野島ルート柏6 号 & c & 12.22 & 2 & 362.25 & 460.07 \\
\hline . & . & - & 4 & 283.01 & 285.84 \\
\hline " & . & . & 6 & 254.70 & 257.25 \\
\hline " & . & . & 8 & 242.57 & 245.00 \\
\hline " & " & " & 10 & 267.78 & 265.13 \\
\hline " & . & . & 12 & 254.55 & 257.10 \\
\hline " & . & . & 14 & 247.50 & 249.98 \\
\hline " & " & . & 16 & 261.12 & 263.73 \\
\hline " & " & 7.52 & 2 & 471.66 & 735.80 \\
\hline " & $"$ & " & 4 & 849.00 & 1324.44 \\
\hline " & $"$ & " & 6 & 636.75 & 993.33 \\
\hline " & $"$ & " & 8 & 849.00 & 1324.44 \\
\hline " & $"$ & $"$ & 10 & 707.00 & 1102.91 \\
\hline " & " & " & 12 & 848.49 & 1323.20 \\
\hline " & $"$ & " & 14 & 742.50 & 1158.20 \\
\hline$"$ & $"$ & $"$ & 16 & 678.90 & 1060.59 \\
\hline
\end{tabular}

\section{表一10 E L 別にみた $\mathrm{E}^{\prime}$ 割線. $\mathrm{E}^{\prime}$ 接線一全荷重 $\mathrm{P}$ 関係（続き）}

\begin{tabular}{|c|c|c|c|c|c|}
\hline 鉄 塔番 号 & 脚 & $\mathrm{EL}(\mathrm{m})$ & 全荷重P $(t)$ & 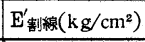 & 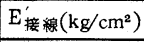 \\
\hline 来島ルートNa 3 号 & b & 74.64 & 2 & 212.25 & 218.63 \\
\hline$"$ & $"$ & " & 4 & 212.25 & 218.63 \\
\hline " & $"$ & " & 6 & 212.25 & 218.63 \\
\hline " & $"$ & " & 8 & 212.25 & 218.63 \\
\hline " & $"$ & $"$ & 10 & 192.83 & 106.05 \\
\hline " & $"$ & " & 12 & 169.73 & 93.35 \\
\hline " & $"$ & 74.14 & 2 & 1061.25 & 1581.27 \\
\hline " & " & " & 4 & 1212.86 & 1807.16 \\
\hline " & " & " & 6 & 636.75 & 948.77 \\
\hline " & " & " & 8 & 1698.00 & 2530.02 \\
\hline " & " & " & 10 & 2121.00 & 3160.29 \\
\hline " & $"$ & " & 12 & 1272.75 & 1896.31 \\
\hline " & " & " & 14 & 1485.00 & 2212.65 \\
\hline " & $"$ & " & 16 & 1697.25 & 2528.91 \\
\hline
\end{tabular}


表一11 繰返し載荷実験最終サイクルの加

荷重過程における|沈下量 $\mathrm{v}_{\mathrm{N}}=\mathrm{w}_{\mathrm{N}}$ - $-\widetilde{\mathrm{w}}$ $\mathrm{N}-1$ の測定

鉄塔番号大久野島ルートN 2 号 (大三島 )

脚 c 脚

実験レベル $\mathrm{EL}=0.97 \mathrm{~m}$

加圧板 (載荷板) 半径 $a=15 \mathrm{~cm}$

\begin{tabular}{|c|c|c|c|}
\hline \multirow{2}{*}{ 荷 } & \multicolumn{2}{|c|}{ 重 } & \multicolumn{2}{c|}{ 量 $\mathrm{v}_{\mathrm{N}}$} \\
\cline { 3 - 4 } & $\mathrm{P}=0 \rightleftarrows 5 \mathrm{t}$ & $\mathrm{P}=0 \mathrm{0}=10 \mathrm{t}$ \\
\hline 全荷重 $\mathrm{P}$ & 荷重強度 $\mathrm{q}$ & $\mathrm{N}=23$ & $\mathrm{~N}=6$ \\
\hline $\mathrm{t}$ & $\mathrm{kg} / \mathrm{cm}^{2}$ & $\mathrm{~cm}$ & $\mathrm{~cm}$ \\
\hline 1 & 1.414 & 0.308 & 0.279 \\
2 & 2.829 & 0.405 & 0.492 \\
3 & 4.243 & 0.470 & 0.577 \\
4 & 5.658 & 0.528 & 0.641 \\
5 & 7.072 & 0.575 & 0.689 \\
6 & 8.487 & & 0.747 \\
7 & 9.901 & & 0.790 \\
8 & 11.351 & & 0.833 \\
9 & 12.730 & & 0.869 \\
10 & 14.144 & & 0.937 \\
\hline
\end{tabular}

表一13 繰返し載荷実験最終サイクル加荷重

猧程における沈下量 $\mathrm{v}_{\mathrm{N}}=\widetilde{\mathrm{w}}_{\mathrm{N}-1}$ の測定 鉄塔番号 大久野島ルートN.6 号 (忠海) $\begin{array}{ll}\text { 脚 } & \mathrm{c} \text { 脚 } \\ \text { 実験レベル } & \mathrm{EL}=6.52 \mathrm{~m}\end{array}$ 加圧板半径 $\mathrm{a}=15 \mathrm{~cm}$

\begin{tabular}{|c|c|c|c|}
\hline \multirow{2}{*}{ 荷 } & \multirow{2}{*}{ 重 } & \multicolumn{2}{|c|}{ 沈下量 $\mathrm{v}_{\mathrm{N}}$} \\
\hline & & $\mathrm{P}=0 \rightleftarrows 5 \mathrm{t}$ & $P=0 \rightleftarrows 10 t$ \\
\hline 全荷重 P & 荷重強度 q & $\mathrm{N}=10$ & $\mathrm{~N}=10$ \\
\hline$t$ & $\mathrm{~kg} / \mathrm{cm}^{2}$ & $\mathrm{~cm}$ & $\mathrm{~cm}$ \\
\hline 1 & 1.414 & 0.040 & 0.060 \\
\hline 2 & 2.829 & 0.080 & 0.100 \\
\hline 3 & 4.243 & 0.108 & 0.133 \\
\hline 4 & 5.658 & 0.129 & 0.162 \\
\hline 5 & 7.072 & 0.153 & 0.186 \\
\hline 6 & 8.487 & & 0.206 \\
\hline 7 & 9.901 & & 0.227 \\
\hline 8 & 11.315 & & 0.244 \\
\hline 9 & 12.730 & & 0.260 \\
\hline 10 & 14.144 & & 0.278 \\
\hline
\end{tabular}

表一12 繰返し載荷実験最終サイクル加荷重過程における 沈下量 $\mathrm{v} N=\mathrm{w}_{\mathrm{N}}-\widetilde{\mathrm{w}}_{\mathrm{N}-1}$ の測定

鉄塔番号 大久野島ルートN 0.3 号 (大久野島 )

脚 $\quad \mathrm{a}$ 脚

実験レベル $\quad \mathrm{EL}=4.01 \mathrm{~m}$

加圧板半径 $\quad \mathrm{a}=15 \mathrm{~cm}$

\begin{tabular}{|c|c|c|c|}
\hline \multirow{2}{*}{ 荷 } & \multirow{2}{*}{ 重 } & \multicolumn{2}{|c|}{ 沈下量 $\mathrm{v}_{\mathrm{N}}$} \\
\hline & & $\mathrm{P}=\rightleftarrows 5 \mathrm{t}$ & $\mathrm{P}=0 \rightleftarrows 10 \mathrm{t}$ \\
\hline 全荷重P & 荷重強度 q & $\mathrm{N}=10$ & $\mathrm{~N}=10$ \\
\hline $\mathrm{t}$ & $\mathrm{kg} / \mathrm{cm}^{2}$ & $\mathrm{~cm}$ & $\mathrm{~cm}$ \\
\hline 1 & 1.414 & 0.092 & 0.105 \\
\hline 2 & 2.829 & 0.148 & 0.169 \\
\hline 3 & 4.243 & 0.188 & 0.218 \\
\hline 4 & 5.658 & 0.217 & 0.254 \\
\hline 5 & 7.072 & 0.246 & 0.285 \\
\hline 6 & 8.487 & & 0.308 \\
\hline 7 & 9.901 & & 0.336 \\
\hline 8 & 11.315 & & 0.356 \\
\hline 9 & 12.730 & & 0.379 \\
\hline 10 & 14.144 & & 0.400 \\
\hline
\end{tabular}

表一14 繰返し載荷実験最終サイクルの加重過程における 沈下量 $\mathrm{v}_{\mathrm{N}}=\mathrm{w}_{\mathrm{N}}-\widetilde{\mathrm{w}}_{\mathrm{N}-1}$ の測定

$\begin{array}{ll}\text { 鉄塔番号 } & \text { 来島ルート爪 } 3 \text { 号 (馬島) } \\ \text { 脚 } & \mathrm{b} \text { 脚 } \\ \text { 実験レペル } & \mathrm{EL}=73.14 \mathrm{~m} \\ \text { 加压板半径 } & \mathrm{a}=15 \mathrm{~cm}\end{array}$

\begin{tabular}{|r|c|c|c|}
\hline \multicolumn{2}{|c|}{ 荷 } & \multirow{2}{*}{ 重 } & \multicolumn{2}{|c|}{ 下 } & 量 $\mathrm{v}_{\mathrm{N}}$ \\
\cline { 3 - 4 } & $\mathrm{P}=0 \leftrightarrows 5 \mathrm{t}$ & $\mathrm{P}=0 \leftrightarrows 10 \mathrm{t}$ \\
\hline 全荷重 $\mathrm{P}$ & 荷重強度 $\mathrm{q}$ & $\mathrm{s}=10$ & $\mathrm{~N}=10$ \\
\hline $\mathrm{t}$ & $\mathrm{kg} / \mathrm{cm}^{2}$ & $\mathrm{~cm}$ & $\mathrm{~cm}$ \\
\hline 1 & 1.414 & 0.023 & 0.023 \\
2 & 2.829 & 0.036 & 0.036 \\
3 & 4.243 & 0.046 & 0.046 \\
4 & 5.658 & 0.054 & 0.055 \\
5 & 7.072 & 0.062 & 0.063 \\
6 & 8.487 & & 0.070 \\
7 & 9.901 & & 0.079 \\
8 & 11.315 & & 0.082 \\
9 & 12.730 & & 0.087 \\
10 & 14.144 & & 0.093 \\
\hline
\end{tabular}

表一15 繰返し載荷実験最終サイクルの荷重過程における $\mu^{\prime}{ }_{\mathrm{N}}$ と $\mathrm{B}^{\prime}{ }_{\mathrm{N}}$ の計算值

\begin{tabular}{|c|c|c|c|c|c|c|c|c|}
\hline 鉄 塔 番 号 & 脚 & $\mathrm{EL}(\mathrm{m})$ & $\begin{array}{l}\text { 最 終 最 大 } \\
\text { 全何重 } \mathrm{P}(\mathrm{t}) \\
\end{array}$ & $\begin{array}{c}\text { n の最大值 } \\
\mathrm{N} \\
\end{array}$ & 折点 & $\mu_{N}^{\prime}$ & $\mathrm{B}_{\mathrm{N}}\left(\mathrm{kg} / \mathrm{cm}^{2}\right)$ & $\begin{array}{l}\text { 計算に用んた } \\
\text { Pの二つの值 }\end{array}$ \\
\hline $\begin{array}{c}\text { 大久野島ルートMa. } 2 \text { 号 } \\
"\end{array}$ & c & $\begin{array}{c}0.97 \\
\prime \prime\end{array}$ & $\begin{array}{r}5 \\
10 \\
\end{array}$ & $\begin{array}{r}6 \\
23 \\
\end{array}$ & $\begin{array}{l}\text { なし } \\
\text { なし }\end{array}$ & $\begin{array}{l}2.616 \\
2.413\end{array}$ & $\begin{array}{l}29.408 \\
27.443\end{array}$ & $\begin{array}{r}5 \mathrm{t}, \quad 2 \mathrm{t} \\
10 \mathrm{t}, \quad 4 \mathrm{t} \\
\end{array}$ \\
\hline $\begin{array}{c}\text { 大久野島ルートNa3 号 } \\
" \prime\end{array}$ & $\begin{array}{l}\text { a } \\
\end{array}$ & $\begin{array}{c}4.01 \\
\prime \prime\end{array}$ & $\begin{array}{r}5 \\
10 \\
\end{array}$ & $\begin{array}{l}10 \\
10\end{array}$ & $\begin{array}{ll}3 \mathrm{t} \\
3 \mathrm{t} \\
\end{array}$ & $\begin{array}{l}1.898 \\
2.017 \\
\end{array}$ & $\begin{array}{l}23.807 \\
24.672\end{array}$ & $\begin{array}{r}5 \mathrm{t}, \quad 3 \mathrm{t} \\
10 \mathrm{t}, \quad 4 \mathrm{t}\end{array}$ \\
\hline $\begin{array}{c}\text { 大久野島ルートNa } 6 \text { 号 } \\
" \prime \\
\end{array}$ & $\begin{array}{l}\mathrm{c} \\
\prime \prime\end{array}$ & $\begin{array}{c}6.52 \\
\prime \prime \\
\end{array}$ & $\begin{array}{r}5 \\
10 \\
\end{array}$ & $\begin{array}{l}10 \\
10 \\
\end{array}$ & $\begin{array}{l}\text { なし } \\
4 \mathrm{t} \\
\end{array}$ & $\begin{array}{l}1.467 \\
1.601 \\
\end{array}$ & $\begin{array}{l}20.835 \\
21.709 \\
\end{array}$ & $\begin{array}{r}5 t, 3 t \\
10 t, \quad 4 t \\
\end{array}$ \\
\hline 来島ルートNa. 3 号 & $\begin{array}{l}b \\
\prime \prime\end{array}$ & $\begin{array}{c}73.14 \\
\prime \prime\end{array}$ & $\begin{array}{r}5 \\
10\end{array}$ & $\begin{array}{l}10 \\
10\end{array}$ & $\begin{array}{l}\text { なし } \\
\text { なし }\end{array}$ & $\begin{array}{l}1.624 \\
1.709\end{array}$ & $\begin{array}{l}22.262 \\
22.915\end{array}$ & $\begin{array}{r}5 \mathrm{t}, \quad 3 \mathrm{t} \\
10 \mathrm{t}, \quad 4 \mathrm{t}\end{array}$ \\
\hline
\end{tabular}




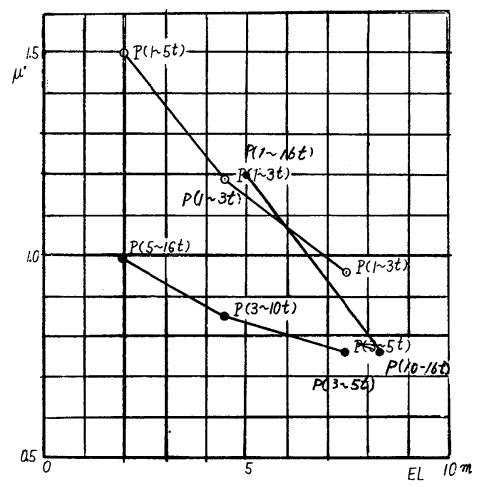

鉄塔番号 大久野ルートNo.2 号 (大三島)

$$
\begin{aligned}
& \begin{array}{cl}
\text { 脚 } & \mathrm{C} \quad \text { 脚 } \\
\text { 実験レベル } & \mathrm{E} \mathrm{L}=7.47 \mathrm{~m} \cdots \cdot . \text {. (1) }
\end{array} \\
& \text { " }=4.47 \mathrm{~m} \text {.......(2) } \\
& \text { " }=1.97 \mathrm{~m} \cdots . . . . \text { (3) }
\end{aligned}
$$

図一１初載荷実験の測定值 $\cdot \mathrm{P}-\mathrm{W}$ 関係の両対数表示

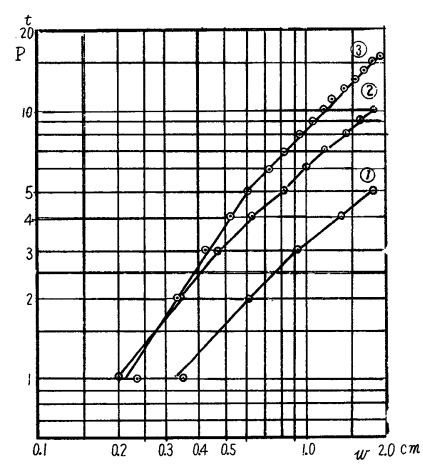

鉄塔番号 大久野ルートNo.2号（大三島）

脚 c 脚

图一 $2 \mu-\mathrm{E} \mathrm{L}$ 関係

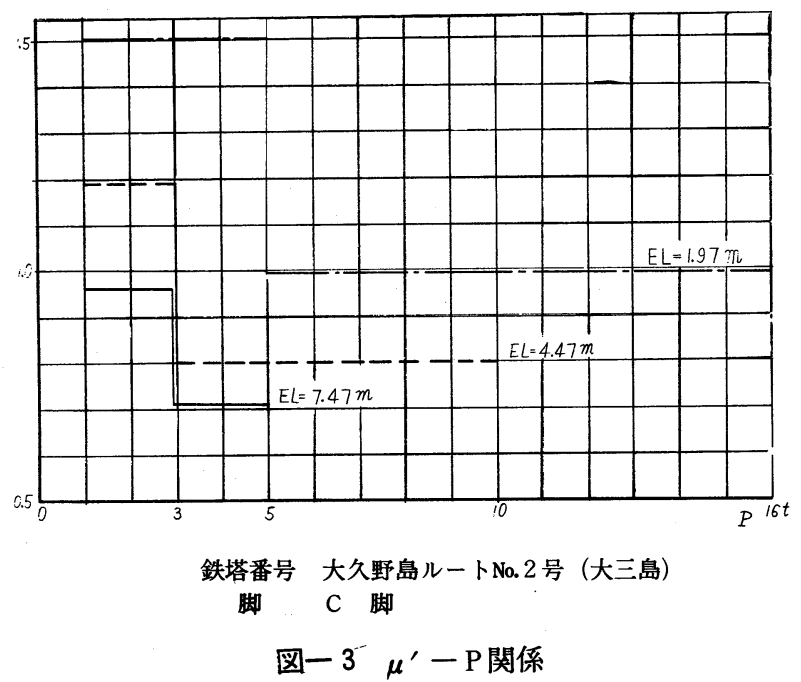

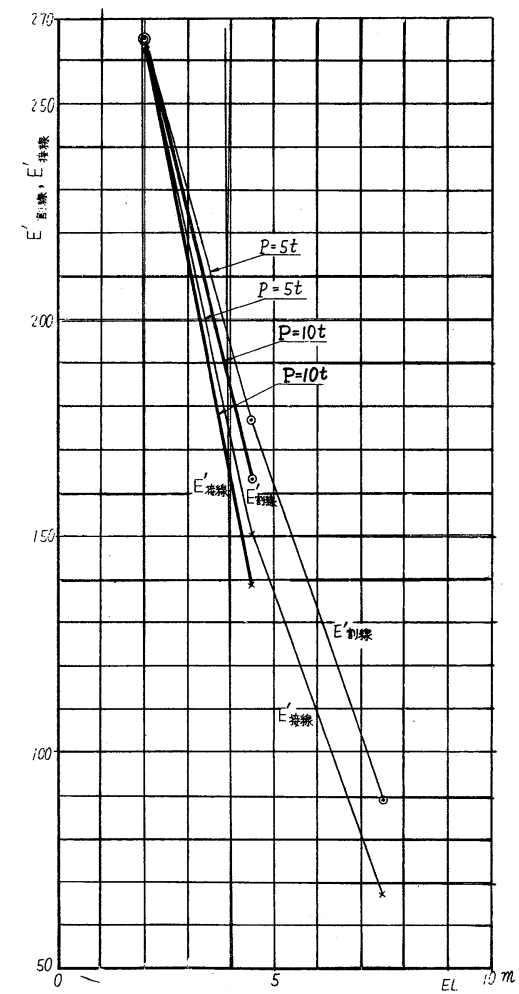

鉄塔 鉄塔番号 大久野島ルートNo.2 号（大三島）

脚 C 脚

$$
\begin{aligned}
& \odot: E^{\prime} \\
& \times: E^{\prime} \text { 割線 }
\end{aligned}
$$

図一 $4 \mathrm{E}^{\prime}$ 割線, $\mathrm{E}^{\prime}$ 接線 $-\mathrm{E} \mathrm{L}$ 関係 

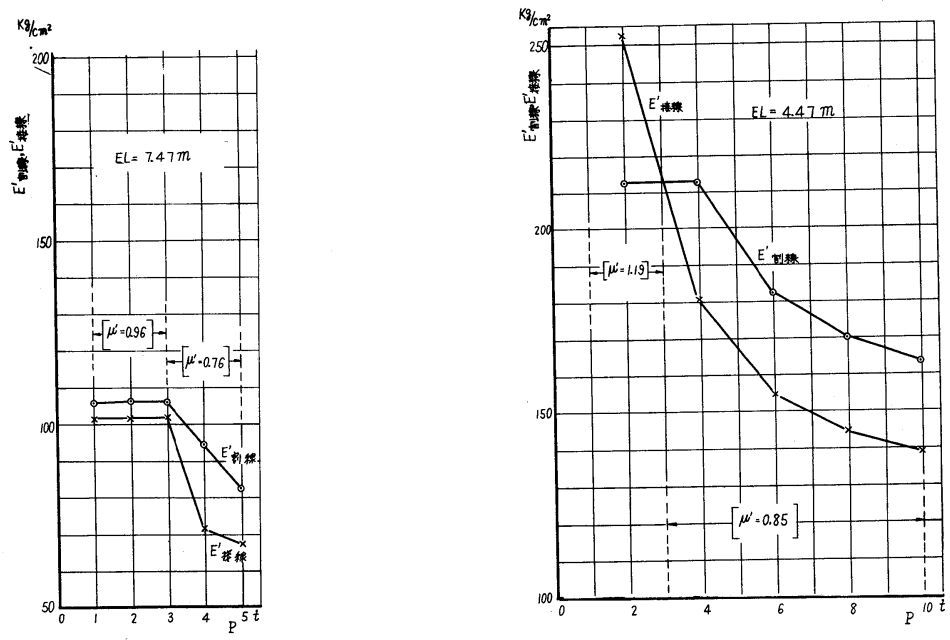

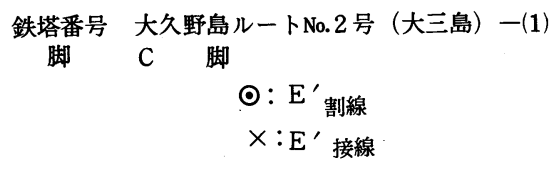

図-5-1 $\mathrm{E}^{\prime}$ 割線, $\mathrm{E}^{\prime}$ 接線 $-\mathrm{P}$ 関係

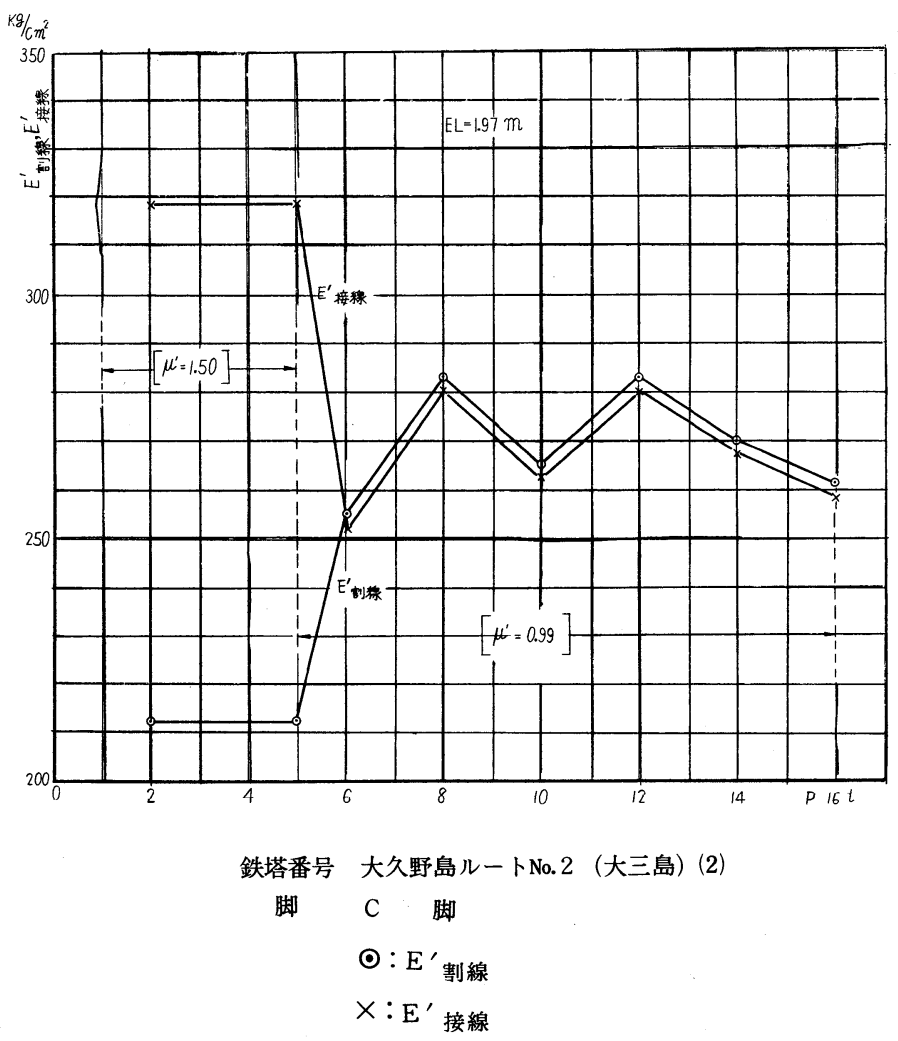

図一 5-2 $E^{\prime}$ 割線 $E^{\prime}$ 接線 $-P$ 関係 (続) 
鉄塔番号 大久野島ルートNo.2 号 (大三島)

脚 C 脚

実験レベル $\mathrm{E} \mathrm{L}=0.97 \mathrm{~m}$

図一6 繰返し載荷実験最終サイクル加荷重過程における $\mathrm{P}-\mathrm{V}_{n}$ 関係の両対数表示
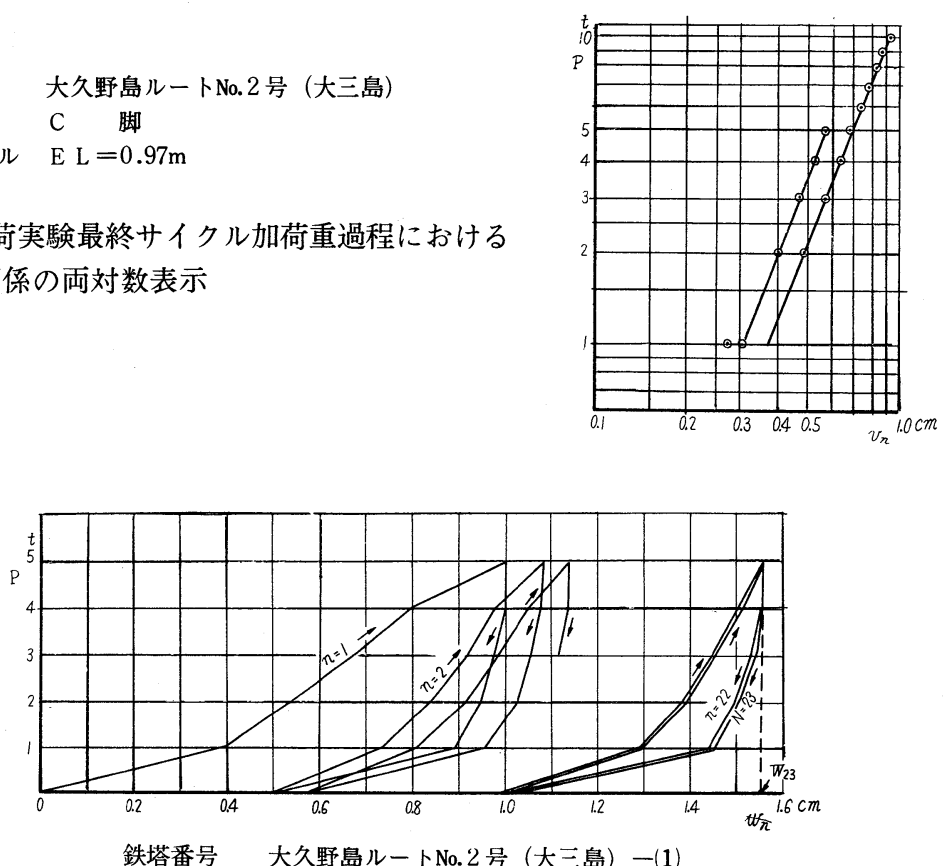

鉄塔番号 大久野島ルートNo.2号（大三島）-(1)

脚 C 脚

実験レベル $\quad \mathrm{E} \mathrm{L}=0.97 \mathrm{~m}$

$\mathrm{P}=0 \rightleftarrows 5$ ton

$\mathrm{n}=1,2, \cdots \cdots, 23$

図-7-1 繰返し載荷実験の $\mathrm{P}-\mathrm{W}_{n}$ 関係

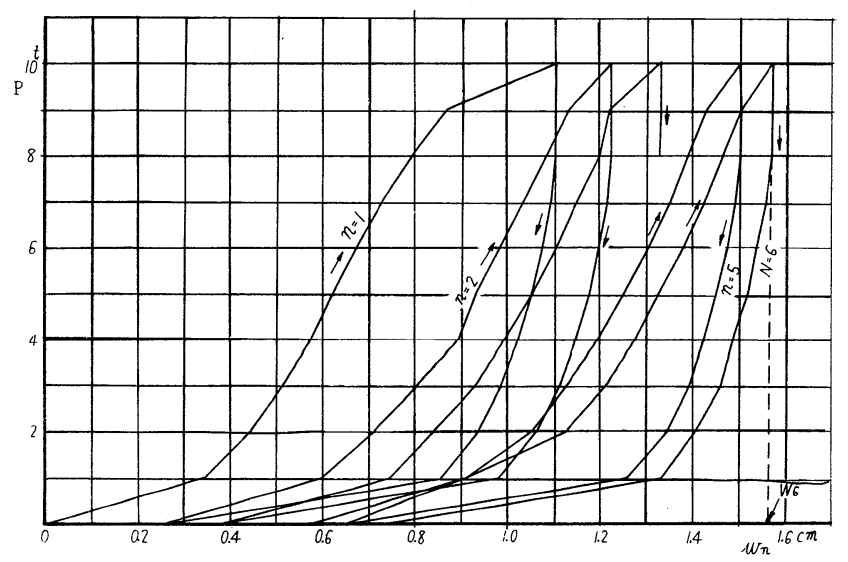

鉄塔番屶 大久野島ルートNo.2岇 (大二島) 一(2)

脚 C 脚

実験レベル $\quad \mathrm{E} \mathrm{L}=0.97 \mathrm{~m}$

$\mathrm{P}=0 \rightleftarrows 10$ ton

$\mathrm{n}=1,2, \cdots \cdots \cdots, 6$

図-7-2 繰返し載荷実験の $\mathrm{P}-\mathrm{W}_{n}$ 関係 

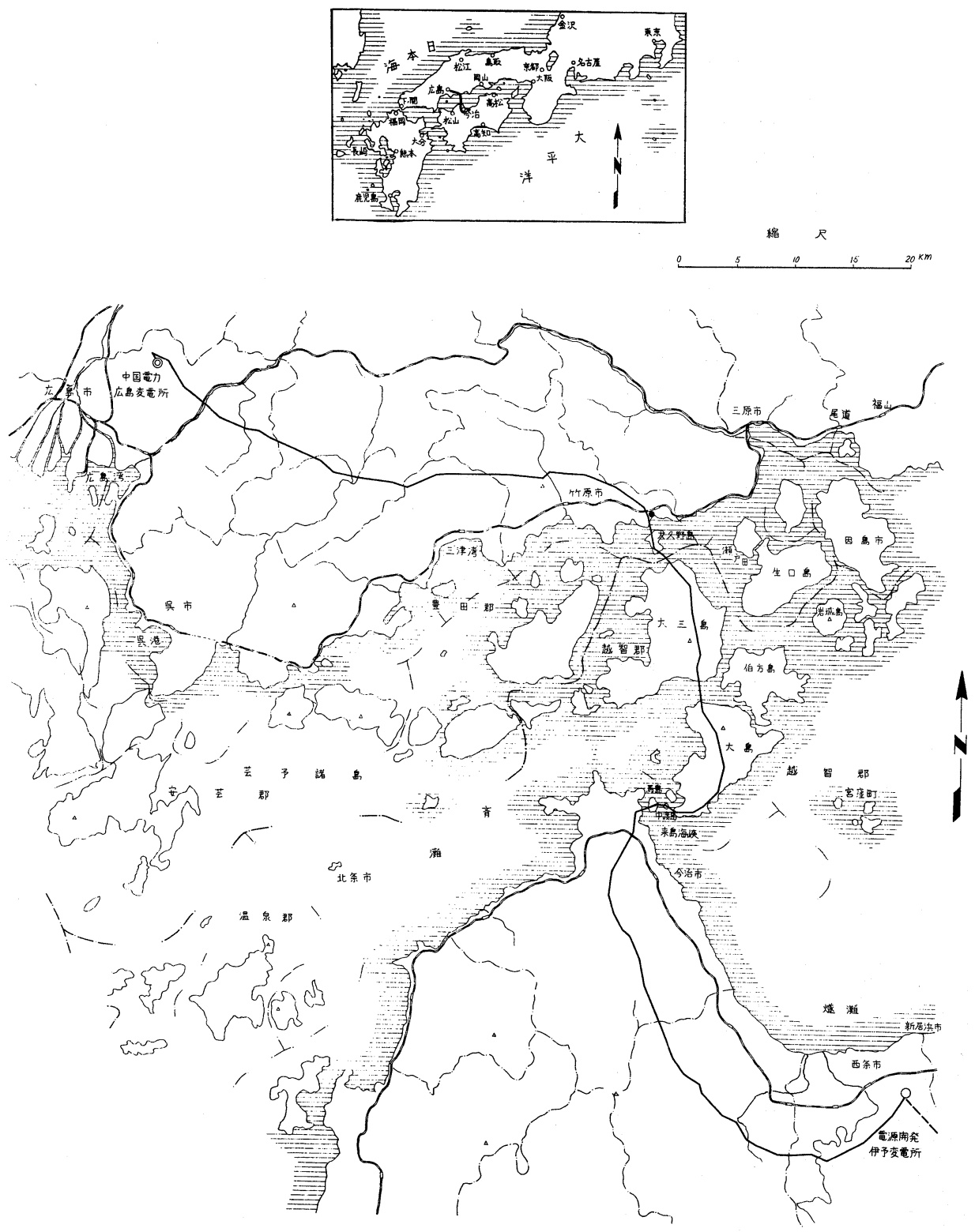

図版一，中四連絡送電線経過地図中四連絡送電線経過地図 


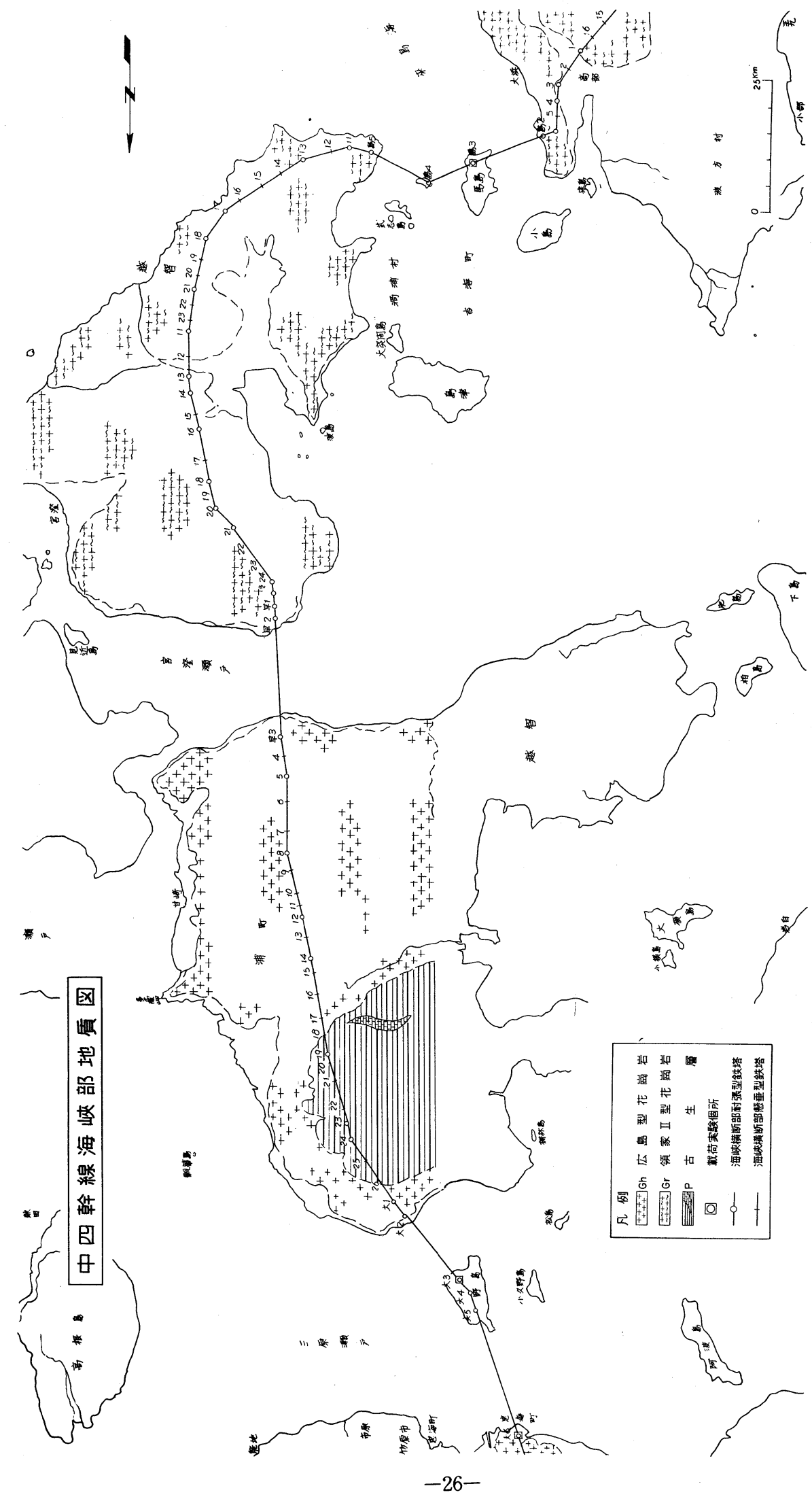

装 

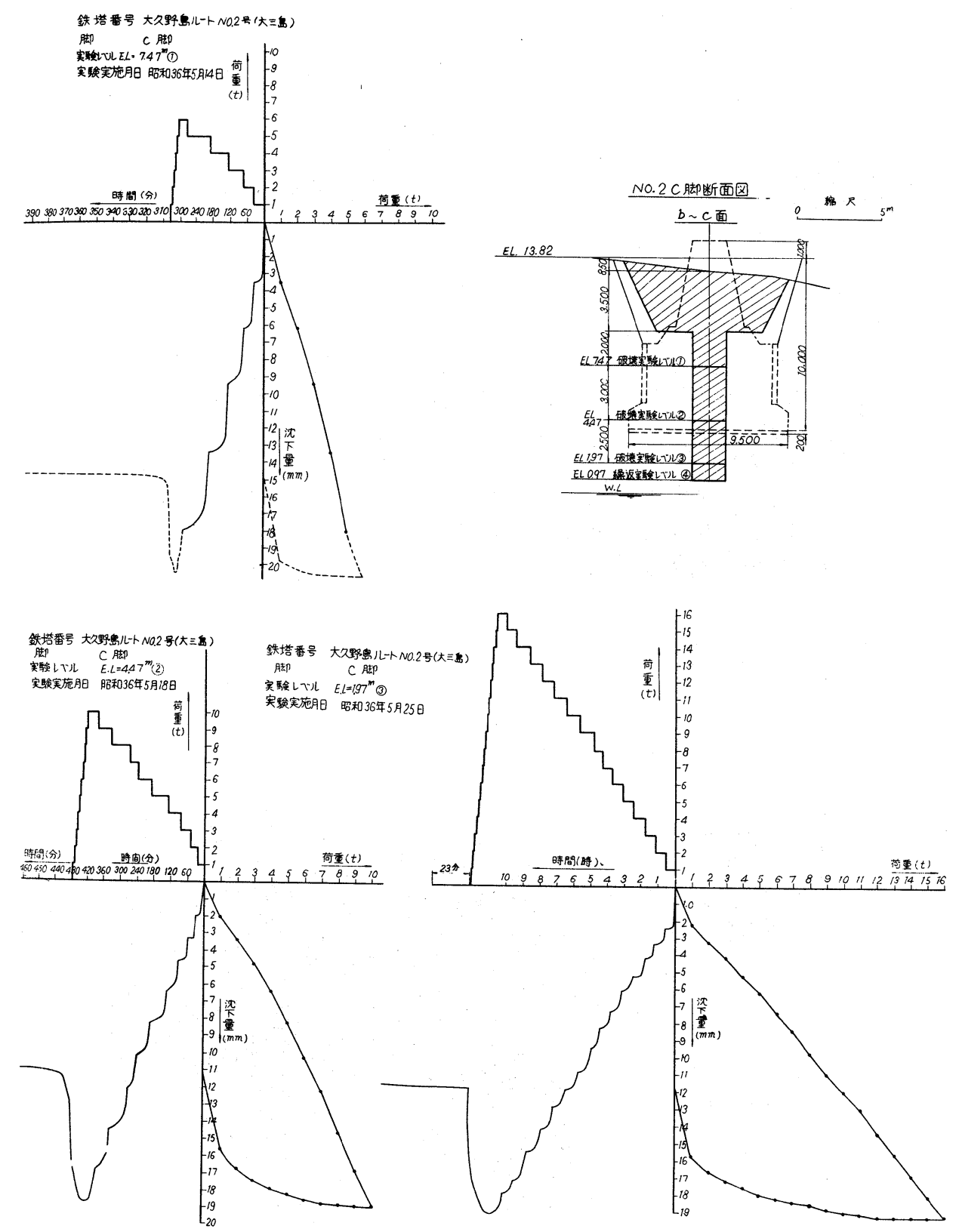

図版一 3 載荷実験結果 -1 


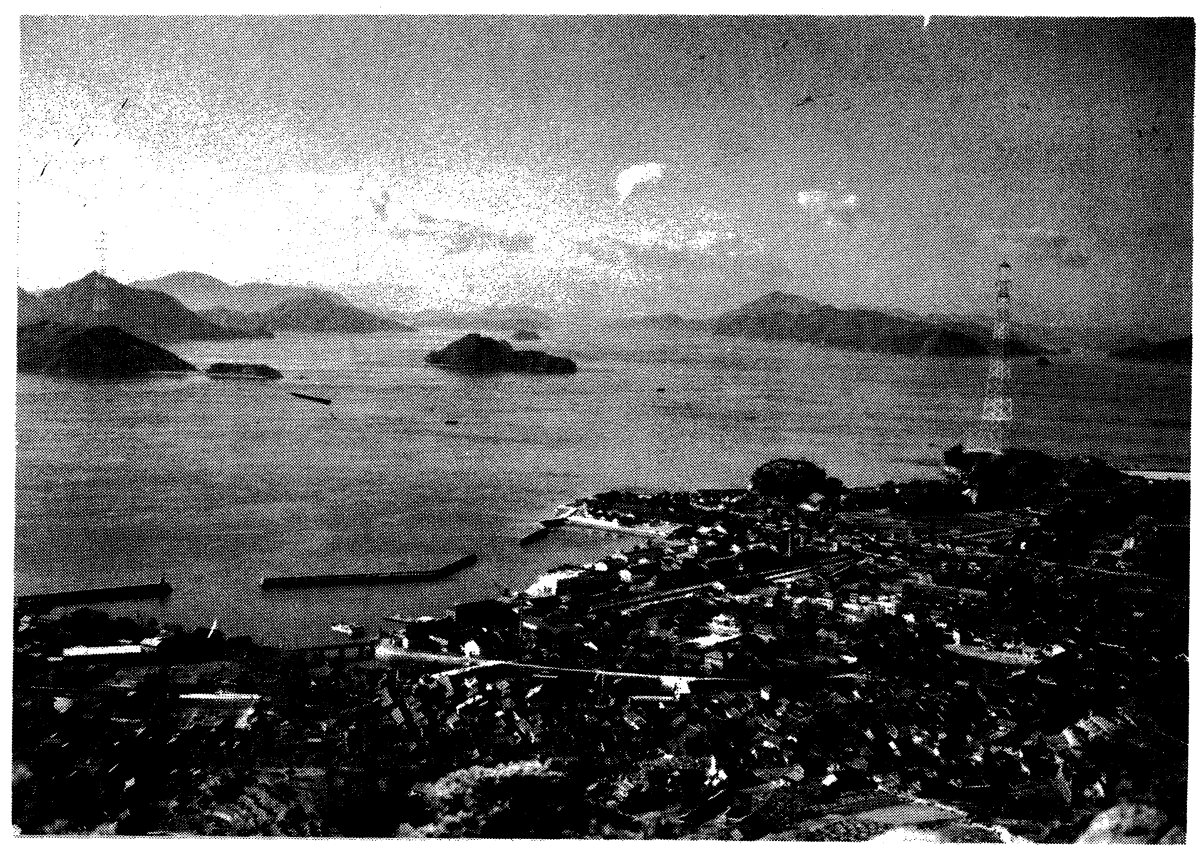

図版一４大久野島ルート 大久野島一忠海間鉄塔

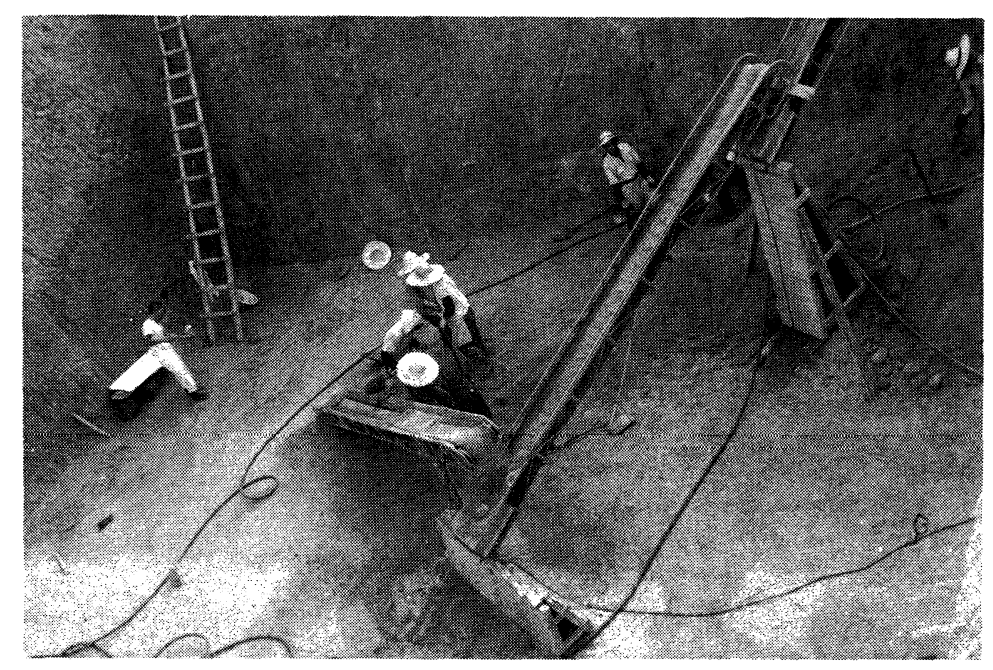

図版一 5 大久野島ルート鉄塔基礎床掘工事中（風化花崗岩一真砂体） 


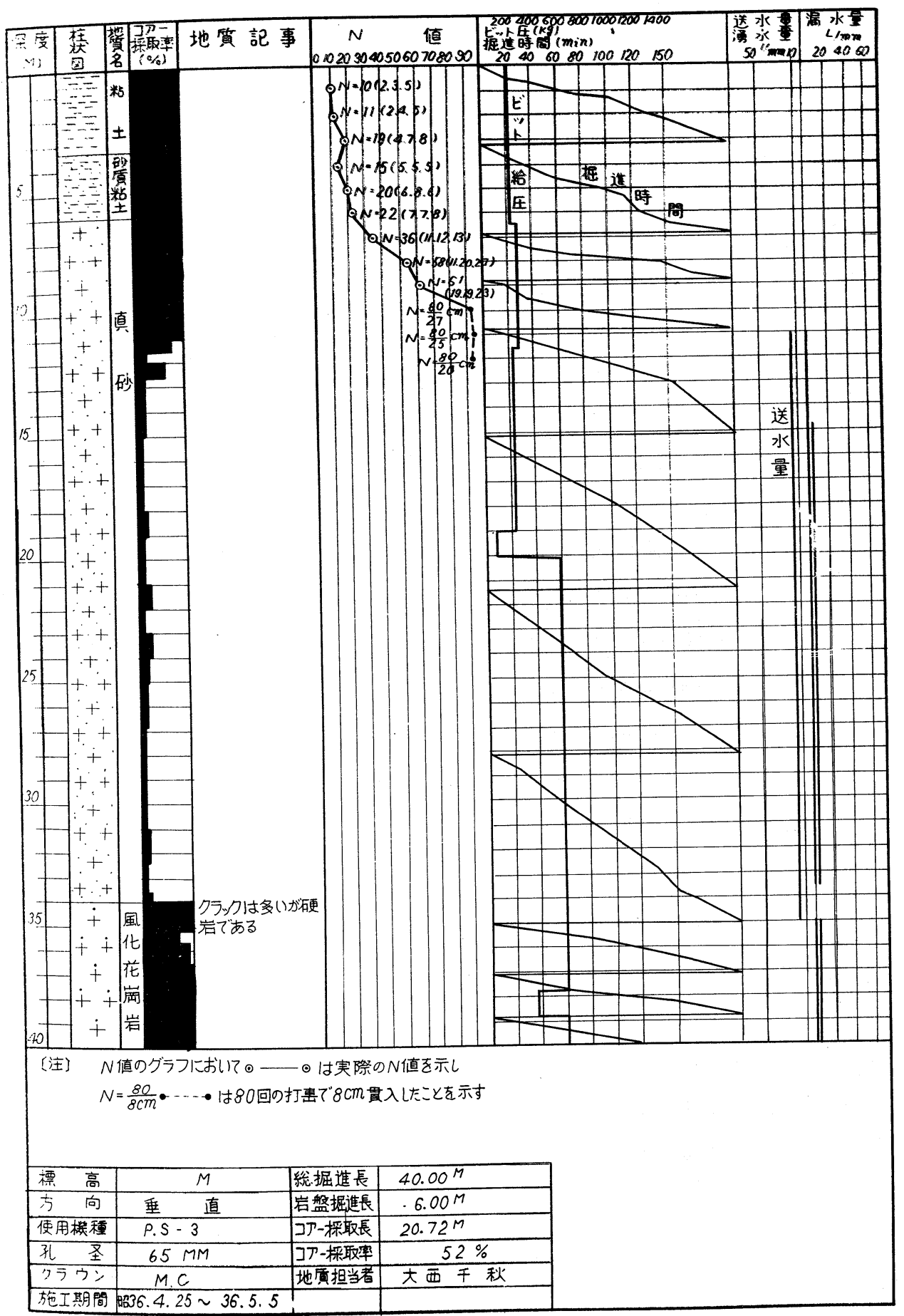

図版 6-1 大久野ルート鉄塔NN. 2 b 脚孔ボーリング柱状図 


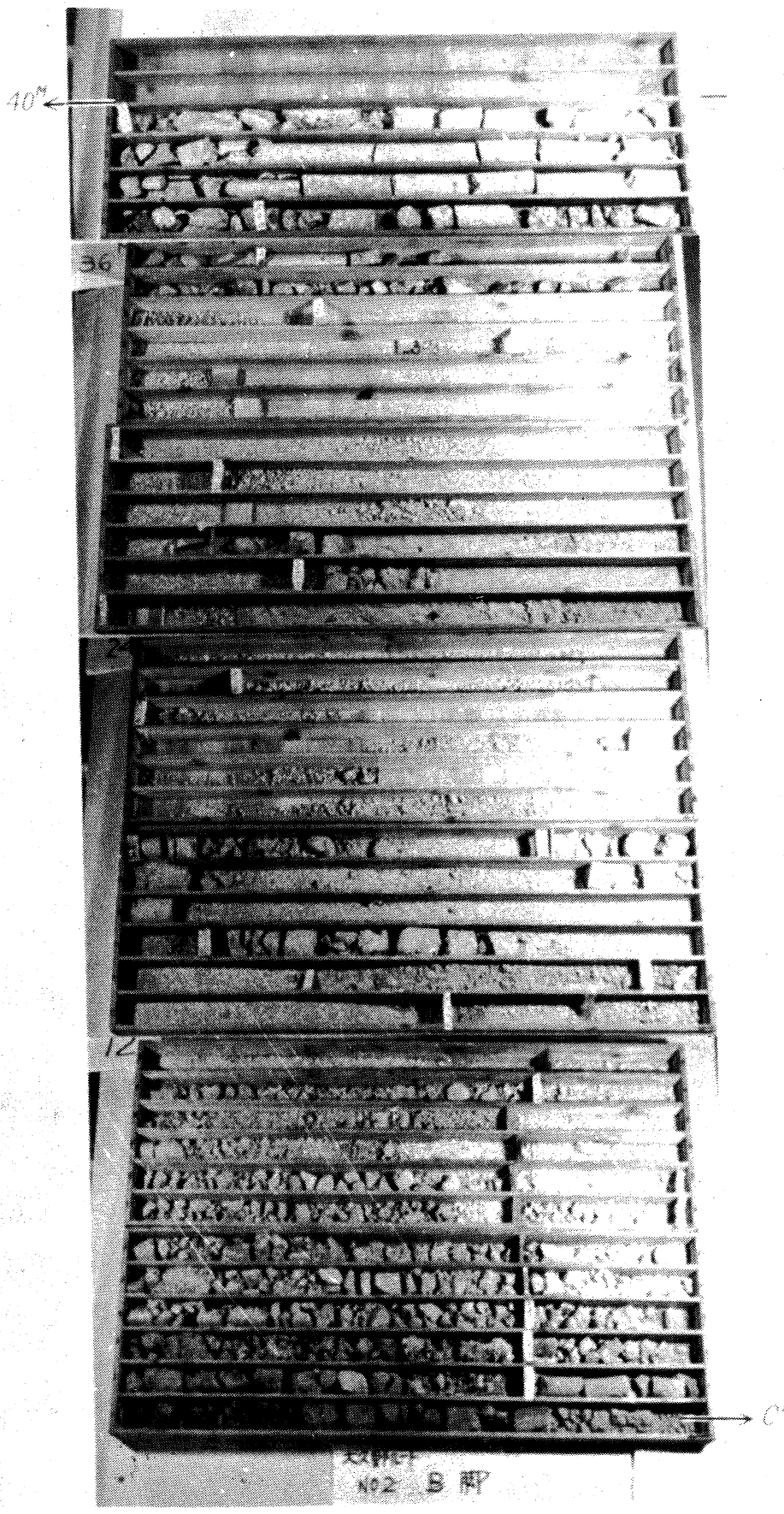

図版一 8 大久野ルート鉄塔NNo. 2 号 b 脚基礎地盤のコアー写真 


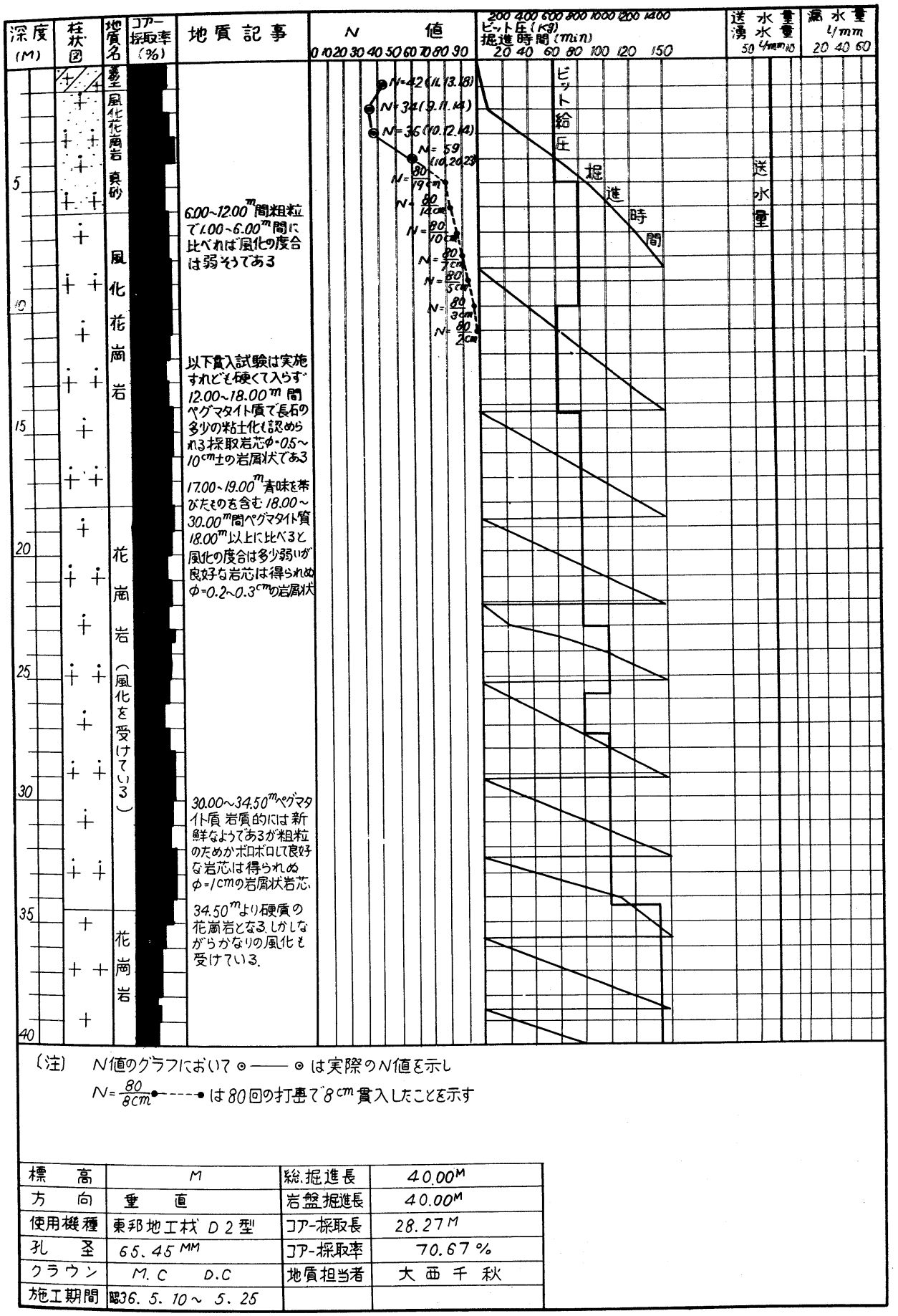

図版 6-2 大久野ルート鉄塔No. $3 \mathrm{~d}$ 脚孔ボーリング柱状図 


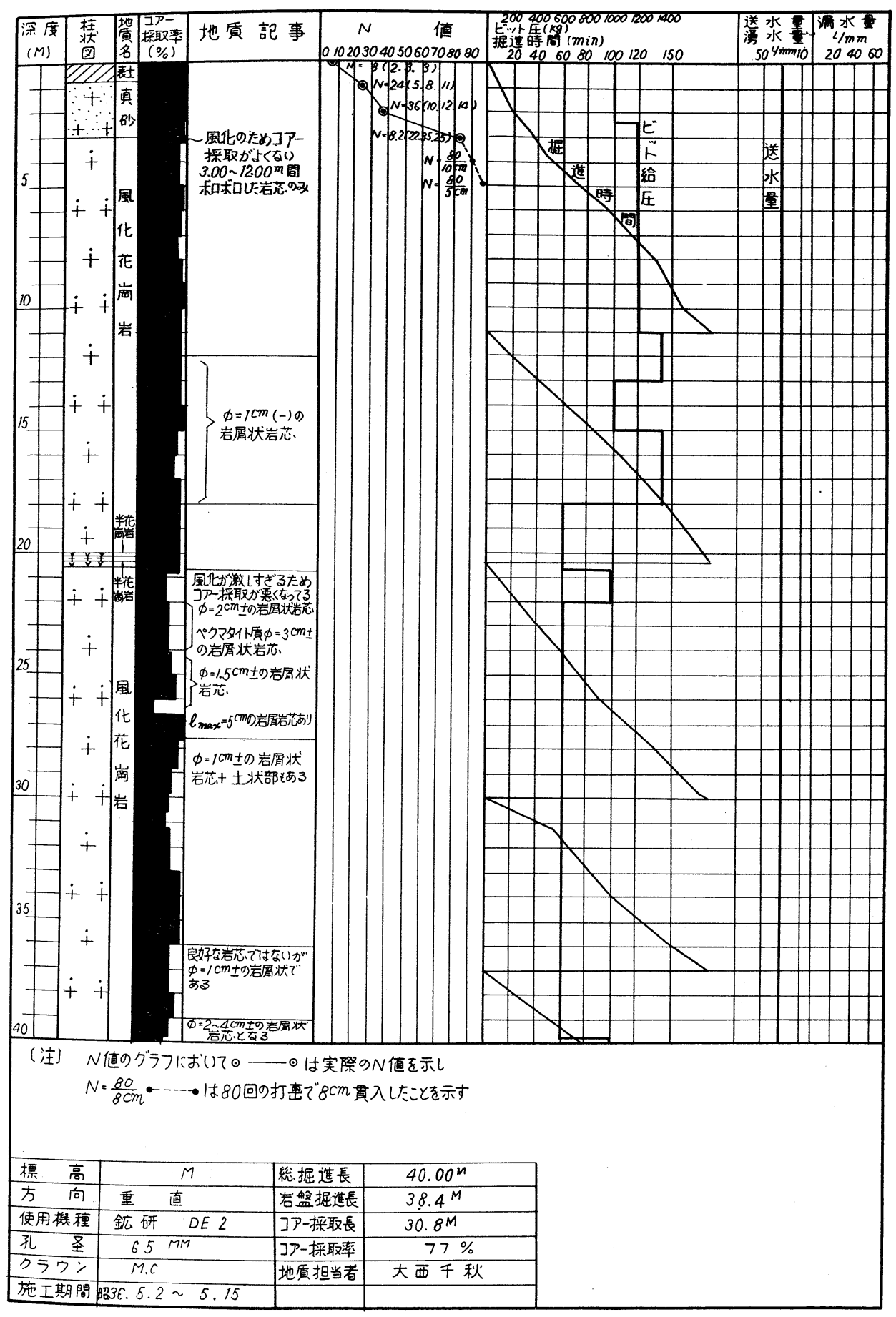

図版 6-3 大久野ルート鉄塔NNo. $6 \mathrm{~d}$ 脚孔ボーリング柱状図 


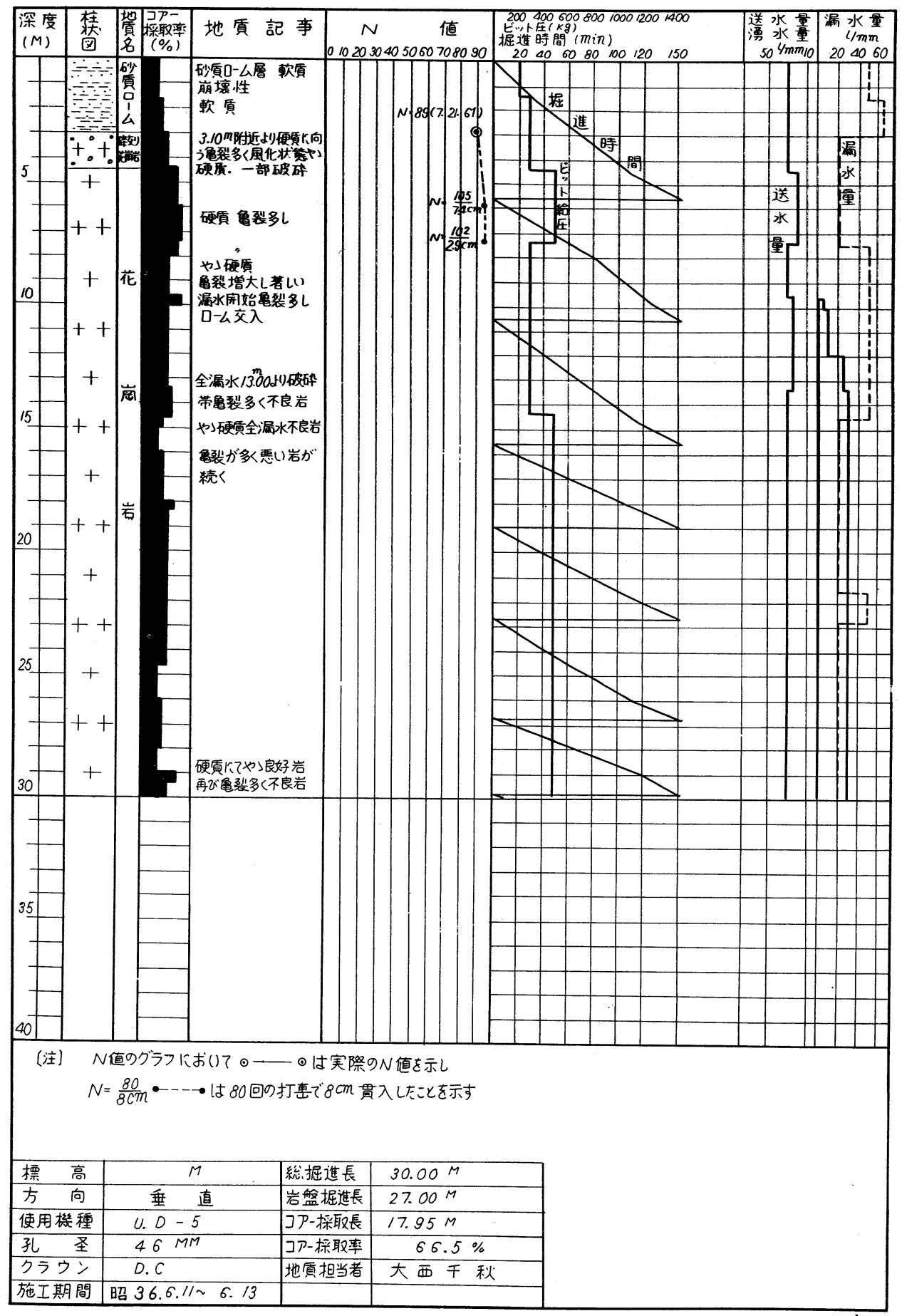

図版 6-4 来島ルート鉄塔No. 3 b 脚孔ボーリング柱状図 


\begin{tabular}{|c|c|c|c|c|c|c|}
\hline \multicolumn{2}{|l|}{ 試 } & Na & \begin{tabular}{|c|} 
大野ルート \\
忠 海
\end{tabular} & \begin{tabular}{|l} 
大久野ルート卜 \\
忠 海
\end{tabular} & $\begin{array}{l}\text { 来島ルート } \\
\text { 波 止浜 }\end{array}$ & \\
\hline \multicolumn{2}{|c|}{ 梁 } & $\mathbf{m}$ & $H=1.00$ & $\mathrm{H}=2.00$ & $\mathrm{D}=2.00$ & \\
\hline \multirow{2}{*}{\multicolumn{2}{|c|}{ 試 料 種 別 }} & 乱さない & $\mathrm{O}$ & $\mathrm{O}$ & $\mathrm{O}$ & \\
\hline & & 乱 し k & & & & \\
\hline \multicolumn{3}{|c|}{ 粒度に上る土の分類 } & 繁混口砂 & 砂 策 & $\begin{array}{l}\text { 簣混り一砂 } \\
\end{array}$ & \\
\hline \multirow{7}{*}{$\begin{array}{l}\text { 粒 } \\
\text { 度 } \\
\text { 試 } \\
\text { 験 }\end{array}$} & 磷 & $\%$ & 31.0 & 46.0 & 30.0 & \\
\hline & 砂 & $\%$ & 55.0 & 45.0 & 56.0 & \\
\hline & $=n 卜$ 分 & $\%$ & 6.0 & 4.0 & 5.0 & \\
\hline & 粘 土 分 & $\%$ & 8.0 & 5.0 & 9.0 & \\
\hline & $60 \%$ 粒 径 & $\mathrm{D}_{60} \mathrm{~mm}$ & 1.6000 & 2.4000 & 1.4000 & \\
\hline & $10 \%$ 粒 径 & $\mathrm{D}_{10} \mathrm{~mm}$ & 0.0090 & 0.0900 & 0.0120 & \\
\hline & 均 等 係 数 & $\mathrm{U}_{\mathrm{C}}$ & 178.0 & 26.7 & 116.6 & \\
\hline 自 & 然 含 水 比 & W \% & 10.37 & 7.87 & 11.24 & \\
\hline 真 & 重 & $\mathrm{G}_{\mathrm{S}}$ & 2.63 & 2.62 & 2.66 & \\
\hline 単 & 位 体 積 重 重 & $r \quad \mathrm{~g} / \mathrm{cm}^{3}$ & 2.22 & 2.22 & 2.23 & \\
\hline 乾 & 燥密 & $\mathrm{rd} \mathrm{g} / \mathrm{cm}^{3}$ & 2.01 & 2.06 & 2.00 & \\
\hline 間 & 比 & $\mathrm{e}$ & 0.32 & 0.27 & 0.33 & \\
\hline 飽 & 度 & $\mathrm{S}_{\mathrm{r}} \%$ & 85.20 & 76.40 & 89.80 & \\
\hline \multirow{4}{*}{$\begin{array}{l}\text { 稠 } \\
\text { 度 } \\
\text { 試 } \\
\text { 験 }\end{array}$} & 液 性 限 界 & $\mathrm{W}_{\mathrm{L}} \%$ & & & & \\
\hline & 塑 性 限 界 & $\mathrm{w}_{\mathrm{p}} \%$ & & & & \\
\hline & 塑 性 指 数 & $I_{P}$ & & & & \\
\hline & 流 動 指 数 & $I_{f}$ & & & & \\
\hline \multirow{2}{*}{$\begin{array}{l}\text { 直断 } \\
\text { 接試 } \\
\text { 乮験 }\end{array}$} & 粘 着 & C $\quad \mathrm{kg}^{\prime} \mathrm{cm}^{2}$ & 0.00 & 0.55 & 0.35 & \\
\hline & 内部摩 蔡 力 & $\phi^{\circ}$ & $34^{\circ} 45^{\prime}$ & $31^{\circ} \quad 30^{\prime}$ & $27^{\circ} 30^{\prime}$ & \\
\hline \multirow{2}{*}{$\begin{array}{l}\text { 三縮 } \\
\text { 䡉試 } \\
\text { 圧験 }\end{array}$} & 粘 着 力 & C $\quad \mathrm{kg} / \mathrm{cm}^{2}$ & & & & \\
\hline & 内部 摩 搮 力 & $\phi^{\circ}$ & & & & \\
\hline \multirow{3}{*}{$\begin{array}{c}\text { 樎 } \\
\text { 軸試 } \\
\text { 王験 }\end{array}$} & 圧 縮 強 度 & qu $\quad \mathrm{kg} \mathrm{Cm}^{2}$ & & & & \\
\hline & 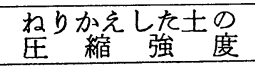 & qur $\mathrm{kg} / \mathrm{cm}^{2}$ & & & & \\
\hline & 敏 & $S_{t}$ & & & & \\
\hline \multirow{4}{*}{$\begin{array}{c}\text { 王 } \\
\text { 密 } \\
\text { 試 } \\
\text { 験 }\end{array}$} & 先 行 荷 重 & $P_{0} \quad \mathrm{~kg} k \mathrm{~m}^{2}$ & & & & \\
\hline & 王 密 係 数 & $\mathrm{C}_{\mathrm{v}} \mathrm{cm}^{2} / \mathrm{sec}$ & & & & \\
\hline & 透水 係 数 & $\mathrm{k} \mathrm{cm} / \mathrm{sec}$ & & & & \\
\hline & 王 維 指 数 & $\mathrm{C}_{\mathrm{c}}$ & & & & \\
\hline
\end{tabular}

図版 7-1 真砂の土質試験結果一覧表 


\begin{tabular}{|c|c|c|c|c|c|c|}
\hline 試料番号 & 偱 奆久野ルート & 圽 & 䂣 分\% & 31.0 & 最大粒往 mm & 9.0 \\
\hline 梁 度 $\mathbf{m}$ & $\mathbf{H}=1.00$ & 験 & 砂 分\% & 55.0 & $60 \%$ 粒径 $\mathrm{D}_{\mathrm{m}}$ & 1.6000 \\
\hline $\begin{array}{l}\text { 粒度火よる } \\
\text { 土の分類 }\end{array}$ & 砂磁 & $\begin{array}{l}\text { 結 } \\
\text { 果 }\end{array}$ & シルト分\% & 6.0 & 有 効 径 $\mathbf{D}_{\mathbf{m}}$. & 0.0900 \\
\hline 分散 剂 & 硅酸ソーダ & & 粘 土 分\% & 8.5 & 均等保数 Uc & 178.0 \\
\hline
\end{tabular}

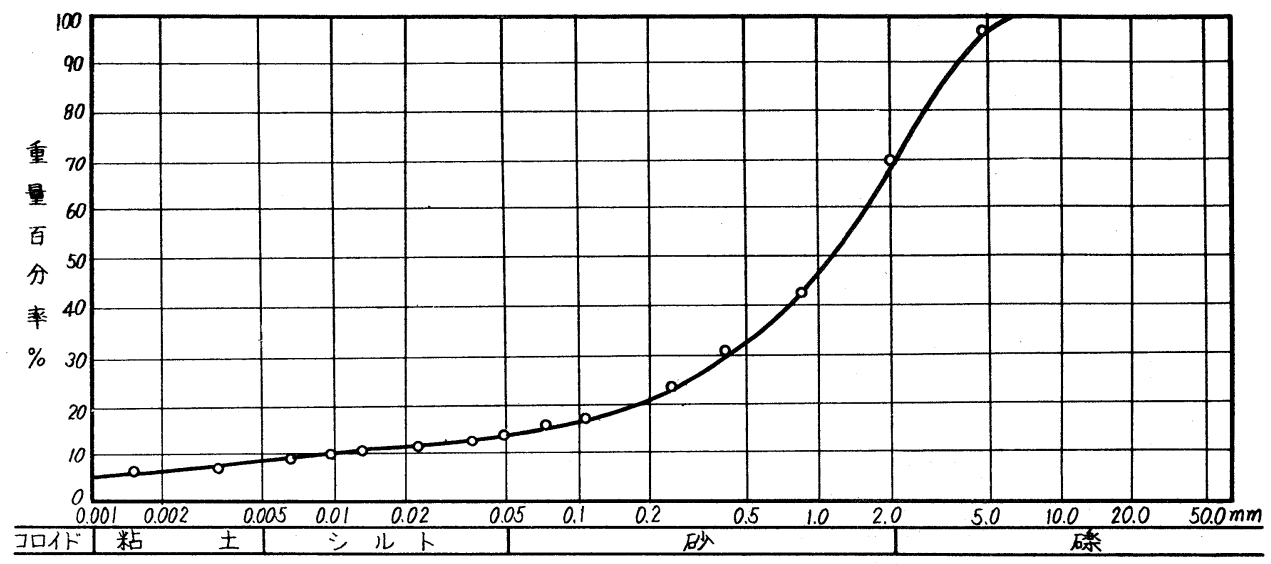

\begin{tabular}{|c|c|c|c|c|c|c|}
\hline 試料番号 & $\begin{array}{ll}\text { Na } & \text { 大久野ルー上 } \\
\text { 忠 海 }\end{array}$ & 試 & 㦡 分\% & 46.0 & 最大粒径 mm & 16.0 \\
\hline 梁 度 $\mathbf{m}$ & $. \quad \mathrm{H}=2.00$ & 験 & 砂 分\% & 45.0 & $60 \%$ 粒径 $\mathrm{D}_{60}$ & 2.4000 \\
\hline $\begin{array}{l}\text { 粒度てよる } \\
\text { 土の分類 }\end{array}$ & 砂礕混 り & $\begin{array}{l}\text { 結 } \\
\text { 果 }\end{array}$ & シルト分\% & 4.0 & 有 効 径 $\underset{\mathrm{m} m}{\mathrm{D}_{10}}$ & 0.0900 \\
\hline 分 散 剂 & 硅 酸ソーダ & & 粘 土 分\% & 5.0 & 均等 係数 $U \mathrm{c}$ & $26.7=6$ \\
\hline
\end{tabular}

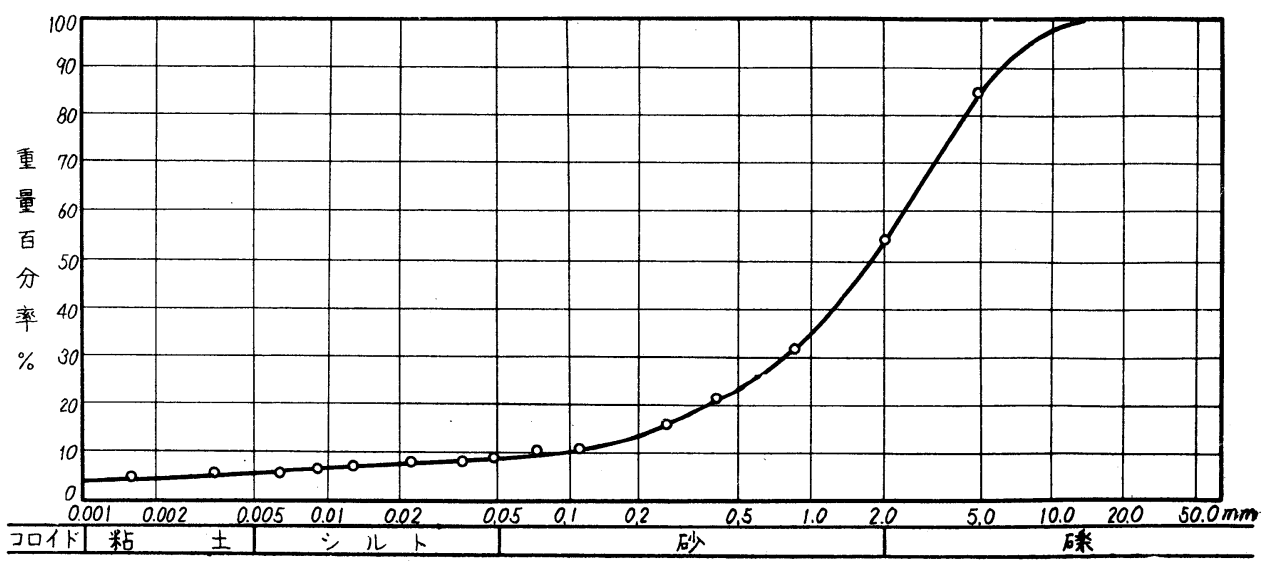

図版 7-2 真砂 の粒度 実験 


\begin{tabular}{|c|c|c|c|c|c|c|}
\hline 試料番号 & $\begin{array}{l}\text { 来島ルー上 } \\
\text { 波 沚 浜 }\end{array}$ & | 試 & 䆆 分\% & 30.0 & 最大粒径 mm & 11.0 \\
\hline 深 度 $\mathrm{m}$ &. $\mathrm{D} \approx 2.00$ & 験 & 分\% & 56.0 & $\begin{array}{r}60 \% \text { 粒径 } \mathrm{D}_{\mathrm{6} 0} \\
\mathrm{~mm}\end{array}$ & 1.4000 \\
\hline $\begin{array}{l}\text { 粒度煌る } \\
\text { 土の分類 } \\
\end{array}$ & 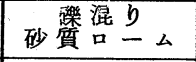 & 結 & シルト分\% & 5.0 & 有 効 径 $\underset{\mathrm{m} \mathbf{m}^{0}}{\mathrm{D}}$ & 0.0120 \\
\hline 分 散 剂 & 硅酸ソーダ & & 粘 土 分\% & 9.0 & 均等係数 U c & 116.6 \\
\hline
\end{tabular}

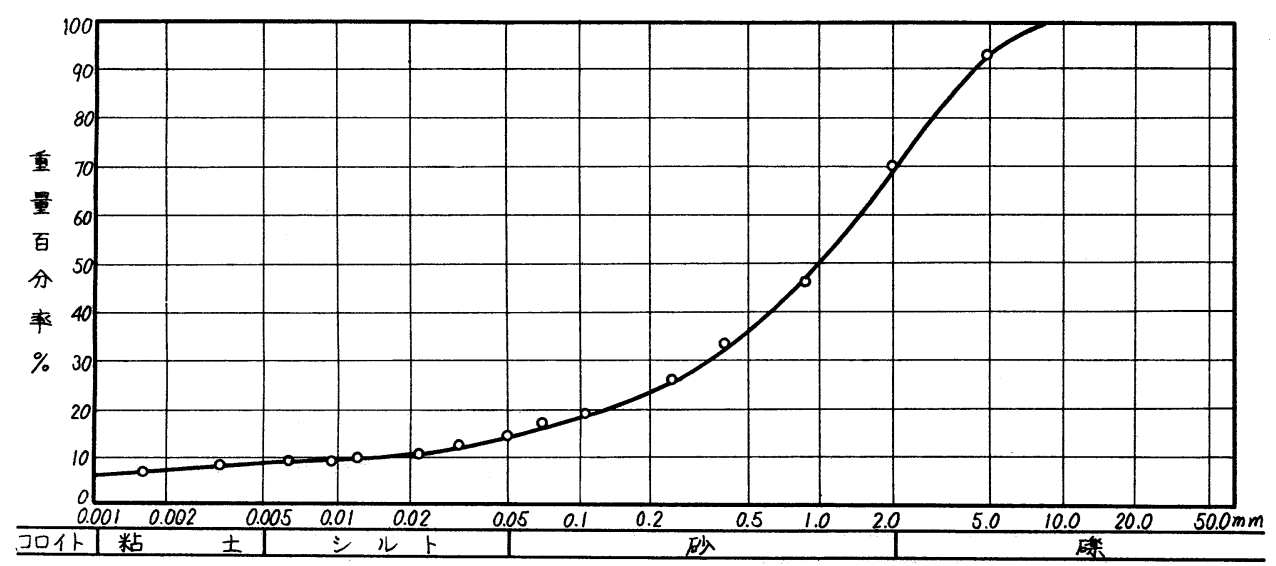

図版 7-3 真砂の粒度実験 